\title{
Frontiers in the economics of crime: lessons for Latin America and the Caribbean
}

Laura Jaitman * (D)

${ }^{*}$ Correspondence:

jaitman.laura@gmail.com Ministry of the Treasury of Argentina, Buenos Aires, Argentina

\begin{abstract}
Crime and violence generate many distortions in the allocation of private and public resources and engender economic and social costs that hinder development. In Latin America and the Caribbean, which is the most violent region on earth, the costs of crime represent at least 3.5\% of the regional gross domestic product, twice as much as in developed countries. Despite the magnitude of the security problem, the region is lagging in the production of rigorous research on crime and the application of evidence-based policies to fight and deter crime. This paper uses the crime economics framework to shed light on the main drivers of crime and proposes avenues for future research and action in the region to reduce crime and its social and economic costs.
\end{abstract}

Keywords: Crime, Costs of crime, Crime policies, Latin America and the Caribbean JEL Classification: K00, K42, O10, O17, O54, Z18

\section{Introduction}

The Latin America and the Caribbean region has made progress in many socioeconomic areas. In the last two decades, the region grew on average more than $3 \%$ annually, with many countries experiencing growth rates close to $4 \%$. With the uptake of growth in the past decade, poverty rates decreased, school attendance and health indicators improved, and many countries reported gains in terms of more inclusive growth.

In contrast to these positive developments, however, crime in the region has increased. Crime and violence are a major concern in Latin America and the Caribbean, where one of every four citizens says that insecurity is the main problem in their lives, even worse than unemployment or the state of the economy. Their concerns are not without reason, as Latin America and the Caribbean is in fact the most violent region on earth. While the region is home to fewer than $9 \%$ of the world's population, it accounts for 33.5\% of the world's homicides according to the United Nations Office on Drugs and Crime (UNODC 2019). Its annual homicide rate of 24 per 100,000 population in 2017 is more than three times the world average, six times that of the United States, and 20 times that of the United Kingdom. Overall, crime imposes significant costs on the Latin American and Caribbean economies, absorbing at least $3.5 \%$ of the region's economic output. This conservative estimate is comparable to the amount the region spends annually on infrastructure (Jaitman 2015, 2017).

(c) The Author(s) 2019. This article is distributed under the terms of the Creative Commons Attribution 4.0 International License (http://creativecommons.org/licenses/by/4.0/), which permits unrestricted use, distribution, and reproduction in any medium, provided you give appropriate credit to the original author(s) and the source, provide a link to the Creative Commons license, and indicate if changes were made. 
Despite the magnitude of the security problem in Latin America and the Caribbean, crime and violence and the public policy response to it have received significantly less research attention than other development disciplines. This relative lack of attention stands in marked contrast to the significant rise in importance and prominence of research on crime and violence in richer countries.

One of the most evident problems is deficient information systems, which result in scarce and unreliable data. Crime statistics in the region are fragmented, inconsistent, and aggregated only to the most macro-levels. The lack of information and weak national statistics systems on crime thwarts accurate diagnosis, monitoring, and evaluation of crime and interventions to counter it.

Many countries are making progress on the statistics front, but the lack of political will and capacity for robust research is an obstacle to finding solutions to the crime problem. A sound research agenda on citizen security is critical to guide policies in this area. Although research on crime economics has been growing in the developed world, in Latin America and the Caribbean this topic is still understudied (Fig. 1). Conducting rigorous research on citizen security programs is difficult in the region. One challenge is of political nature: security in the developing world is a sensitive topic closely related to public opinion and to political concerns. Citizen security interventions are often driven by politics, dogma, and emotions. The dissemination of research projects is frequently obstructed when those projects run counter to established political gains, expose corruption, or simply are considered by political operators to undermine society's perception of security. The high rotation of public servants in this area also precludes longer-term research projects.

The objective of this paper is to gain a better understanding of the crime situation in the region and develop an informed discussion on its potential drivers and solutions. For that purpose, a crime economics framework is employed, as it provides a useful setting

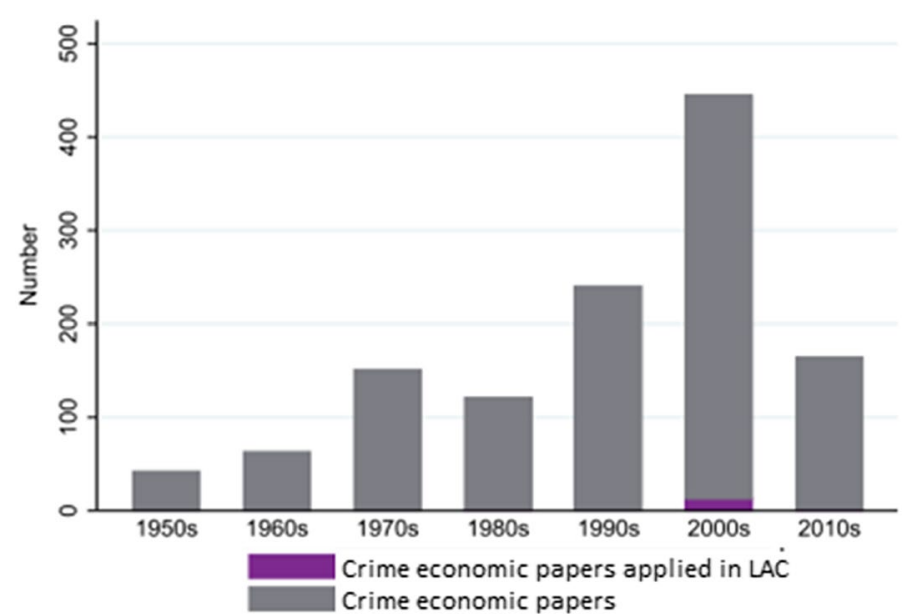

Fig. 1 Papers on economics of crime in leading economics journals. Journals include Econometrica, Economica, Journal of Law and Economics, Journal of Political Economy, The American Economic Review, The Bell/ RAND Journal of Economics, The Economic Journal, The Quarterly Journal of Economics, The Review of Economic Studies, and The Review of Economics and Statistics. LAC: Latin America and the Caribbean (Source: Adapted to Latin America from Draca and Machin (2015)) 
to analyze in a pragmatic rather than ideological way the different crime prevention and crime control strategies.

The study of crime using an economic framework and explicitly including deterrence considerations can be traced to the late eighteenth century (Posner 2004) with Cesare Beccaria's Dei delitti e delle pene in 1764 and Jeremy Bentham's Introduction to the Principles of Morals and Legislation in 1780. The most influential work on the crime economics movement is arguably "Crime and Punishment: An Economic Approach" (Becker 1968).

In its most stylized form, Becker's model proposes that criminals are rational individuals who compare the expected cost and benefit of committing crimes and conducting legal activities, and then select the option with the higher expected net payoff. This basic model is very general and flexible (Polinsky and Shavell 1999; Lee and McCrary 2009, develop a more refined version).

Through this lens, high crime rates are a consequence of the higher expected net benefits from illegal activities for prospective criminals. This is due to a low expected return to education or legal jobs, or to a low expected cost of committing crimes (for example, because of the low probability of apprehension), or most likely a combination of both factors.

Social prevention interventions are intended to increase the payoff of legal activities, thus making crime less attractive. In the case of social prevention activities targeting youths, a training or employability program increases the possibilities of labor market attachment and, thus, potential earnings in the legal sector, ultimately reducing the attractiveness of criminal activity. Inside prisons, rehabilitation programs are intended to achieve similar objectives, raising the benefits of legal behavior upon release.

Other interventions may increase the expected cost of committing crimes, thus having a deterrence effect on prospective criminals. These interventions operate on three levels: the certainty, severity, and celerity of punishment. Certainty refers to the probability of legal sanctions given the commission of a crime, and touches on all elements of the criminal justice system from policing to the judiciary. Severity refers to the onerousness of the sanction imposed, which is related not only to norms of punishment, but also to the characteristics of prisons. Celerity, which is less studied, refers to the lapse in time between the commission of a crime and its punishment, which again depends on decisions at all stages of the criminal justice system (Nagin 2013).

The literature on crime economics has evolved for the most part empirically to test different implications of the Becker model mainly related to an increase in the severity and certainty of punishment and the improvement of the returns to legal activities (educations and jobs). This paper reviews the evidence, which is concentrated in developed economies, and shows the implications for improving security policies in Latin America and the Caribbean.

However, there are important questions in the crime economics literature that are still unsettled in the growing body of research even for developed countries, and that are relevant for the Latin American and Caribbean context. For example, the impact of changes in economic incentives in terms of the returns to committing crimes has not been developed in the literature. This is very important because most crimes are acquisitive, and studying how illegal markets function can advance the understanding of 
criminal behavior and networks and how to fight them (see Galiani et al. 2019 for recent extensions to the traditional Becker model).

The next section of this paper reviews the crime situation in Latin America and the Caribbean compared to other regions and describes some features of the heterogeneity within the former. Section 3 outlines the main framework of crime economics using the Becker (1968) model and its most recent extensions to add a dynamic component to the originally static model of crime. Section 4 relates the policy implications of the model to the empirical evidence in developed countries and in Latin America and the Caribbean. The paper concludes by proposing concrete areas for future research and action that are particularly relevant for Latin America and the Caribbean.

\section{Crime and violence in Latin America and the Caribbean}

Crime and violence in Latin America and the Caribbean is pervasive: it is the world's most violent region. With 24 homicides per 100,000 inhabitants in 2017, Latin America and the Caribbean accounts for 33.5\% of the world's homicides, despite being home to less than $9 \%$ of the world's population. Africa accounts for another third of global homicides, with Asia trailing at 23\%. Europe and North America distantly follow, with only 5 and 3\% of the total, respectively (UNODC 2019). Thus, the homicide rate in Latin America and the Caribbean is more than three times the world average of 6.1 per 100,000 population for 2017 (Fig. 2). Not only are the region's murder levels high, but also recent trends are worrisome. While in many regions (such as sub-Saharan Africa), the homicide trend is decreasing and drives downwards the global trend, Latin America and the Caribbean is the only region where violence remains high and has continued to increase since 2005 .

The aggregate levels of violence mask a great deal of heterogeneity: the variance across sub-regions and countries within Latin America and the Caribbean is staggering. Central America has the highest incidence of homicides (25.9 homicides per 100,000 population). South America rate has been increasing to 24.2 per 100,000 population and the Caribbean registered 15.1 homicides per 100,000 population in 2017.

In South America, there are countries with persistently high homicide rates, including Brazil, Colombia and Venezuela. In Colombia, there has been a decrease in the homicide rate from 80 per 100,000 population in 1991 to 25 in part due to the State actions against drug trafficking. On the contrary, Venezuela in the same period experiences a dramatic increase from a rate of 13 homicides per 100,000 population to 57 homicides per 100,000 population in 2017. Brazil has experienced an increase to 30 homicides per 100,000 population (with some states in the Northeast exceeding 50 homicides per 100,000 population) even after having rates between 20 and 26 in the past decade. It is estimated that between 1991 and 2017, 1.2 million people died as a result of an intentional homicide in Brazil (UNODC 2019). The other countries in South America have low homicide rates for the region. For example, in Argentina homicides have decreased steadily in the last 4 years to 5.3 per 100,000 population in 2017 . Chile is the country of the region with the lowest homicide rate, around 4 per 100,000 population.

In Central America, El Salvador and Honduras had respective rates in 2017 of 62 and 42 homicides per 100,000 population, well above the regional average, and in 2015, El Salvador's homicide rate was above 100 per 100,000 population. In this region, the 

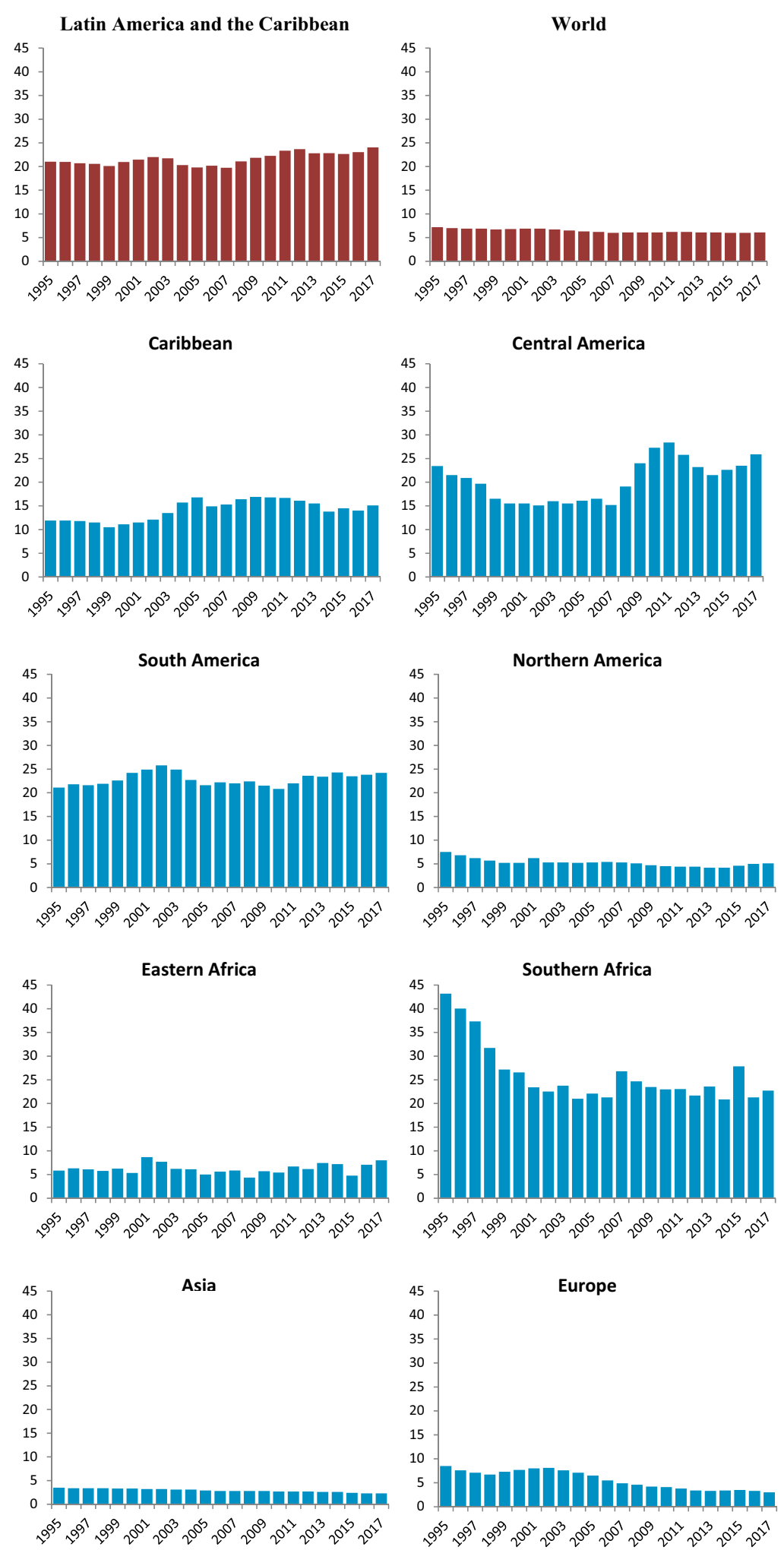

Fig. 2 Intentional homicide rates per 100,000 population, 1995-2017 (Source: Produced by the author based on UNODC (United Nations Office on Drugs and Crime) (2019) database) 
variability and high level of homicides are related to the dynamics of gangs and organized crime groups (UNODC 2019). The Caribbean also has high levels of interpersonal violence, mainly related to gun crimes. Homicide rates in Jamaica soared to 56 per 100,000 population in 2017. On average, the Southern Cone and the Andean subregion show lower homicide rates, although there is heterogeneity within each of the countries. Brazil has the highest rate in South America with a nationwide average in 2017 of 30 homicides per 100,000 population.

In the Southern Cone, where homicide rates are not so high in regional terms in most of the countries, there are high levels of property crimes. Thefts and robberies rates in Uruguay and Argentina are above 1000 per 100,000 population. The situation in terms of theft at a regional level is an even more endemic problem. Although the data are less reliable in terms of comparability and more dated than those for homicides, it is clear that theft is disproportionately common in Latin America. Data reveal that in less than one decade, the robbery rates in many Latin American and Caribbean countries have dramatically increased, becoming more of a daily occurrence than an exception. Equally worrisome is the fact that, on average, 6 out of 10 robberies in the region are violent (UNDP (United Nations Development Programme) 2013). Assaults are also very prevalent in Central America and the Caribbean. As of 2015, Guyana, Barbados, and Grenada had the highest rates at 1208,519 , and 462 per 100,000 population, respectively.

The Latin America and Caribbean region also has high rates of violence against women, which points to a serious problem that engenders many welfare costs. According to WHO (WHO (World Health Organization) 2013), 29.8\% of women in the region have experienced physical and/or sexual intimate partner violence during their lifetime. The corresponding figure is $23.2 \%$ in high-income countries (North America and Western Europe), but increases to $37.7 \%$ in Southeast Asia and 37\% in the Eastern Mediterranean. Considering only non-partner sexual violence, the prevalence among Latin American and Caribbean women is close to that observed in Africa (10.7\% for the former and $11.9 \%$ for the latter), and much higher than in Europe (5.2\%) or even Southeast Asia (4.9\%).

The reasons for these high levels of violence remain unclear (see for example Di Tella et al. 2010 for some potential drivers). Levels in the region vary, with elevated homicide rates in countries with high, medium, as well as low levels of human development. Some Latin American and Caribbean countries have service economies, while the economies of others are driven by the extraction of raw materials, agriculture, or manufacturing. In addition, the region includes countries with very large populations as well as countries with very small populations.

Looking at some fundamental variables that could explain crime, such as wealth, inequality or poverty, Latin America and the Caribbean is an outlier. For example, Fig. 3 shows that the region has an extraordinary level of violence relative to other regions with comparable levels of economic development, as proxied by the Gross Domestic Product (GDP) per capita. The grey line, which shows the partial correlation of the homicide rate and GDP per capita (controlling for inequality and poverty), confirms this negative relation. Looking at Latin American and Caribbean countries, most are far above the regression line (the grey line showing adjusted values). Thus, Latin America and the Caribbean are an outlier for crime given its income level, as 


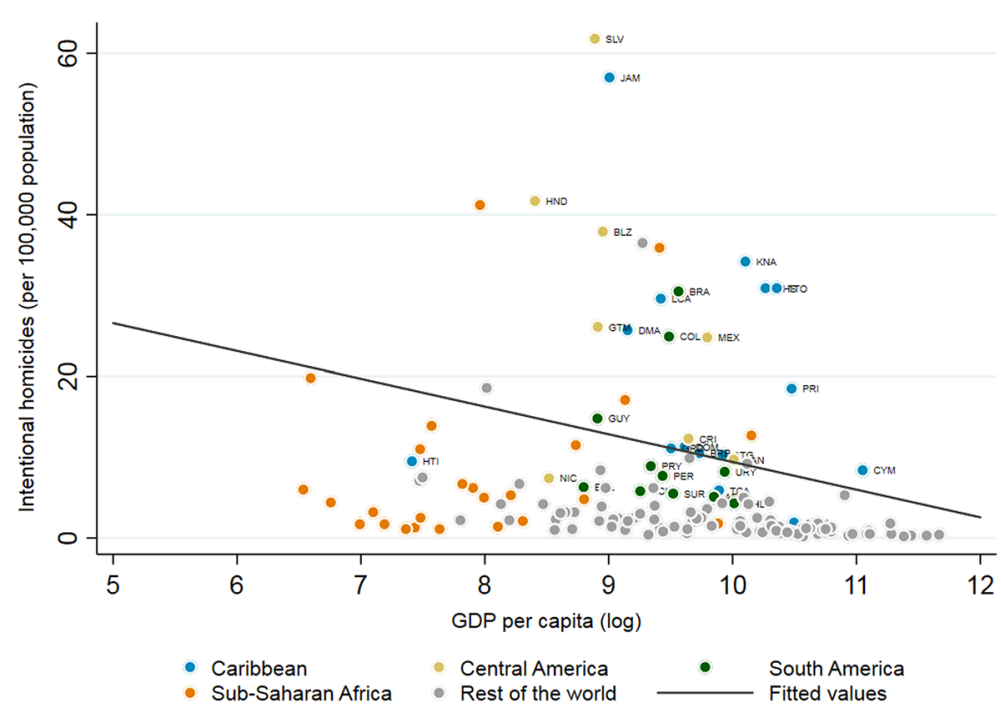

Fig. 3 Homicide rates and per capita gross domestic product, 2017 or latest year available (Source: Produced by the author based on UNODC and World Bank database)

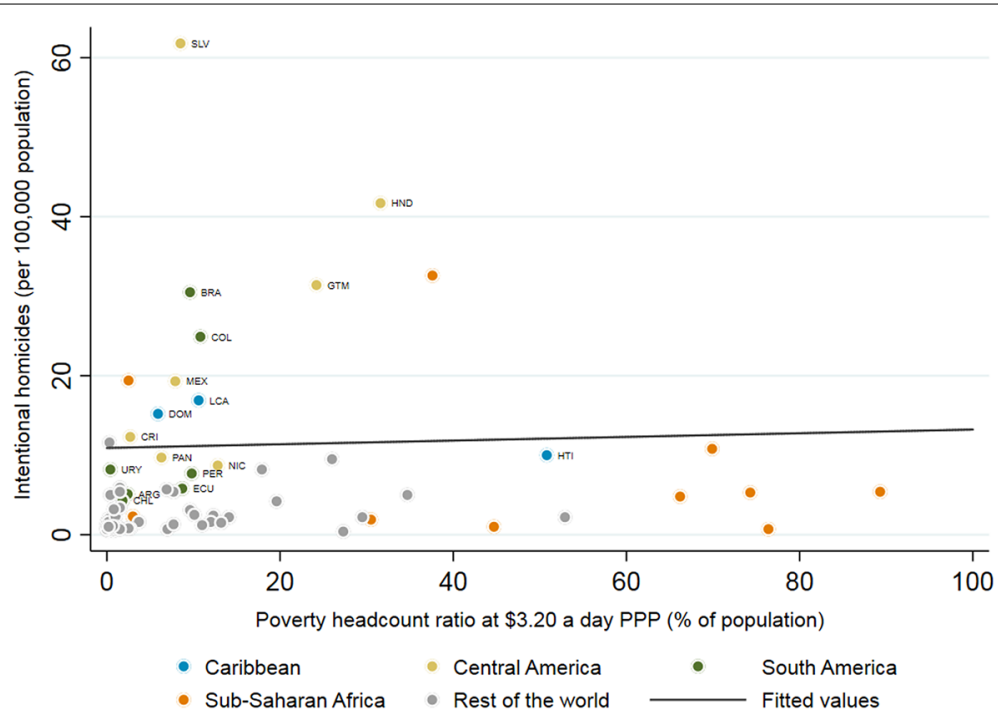

Fig. 4 Homicide and poverty rates, 2017 or latest year available. PPP purchasing power parity (Source: Produced by the author based on UNODC and World Bank database)

its countries' homicide rates are higher than they should be given their income levels (which is not explained by the fact that Latin American and Caribbean countries might be poorer or more unequal). Figure 4 shows a similar pattern when analyzing the relationship between homicide rates and poverty (partial correlation, controlling for GDP per capita and inequality). It is clear that although the proportion of poor people is relatively low in Latin America and the Caribbean, the incidence of violence is very high, and higher than for poorer countries in other regions. Along these same lines, Fig. 5 shows that Latin American and Caribbean countries are very unequal, based on the Gini coefficient. However, their homicide rates are much higher than 


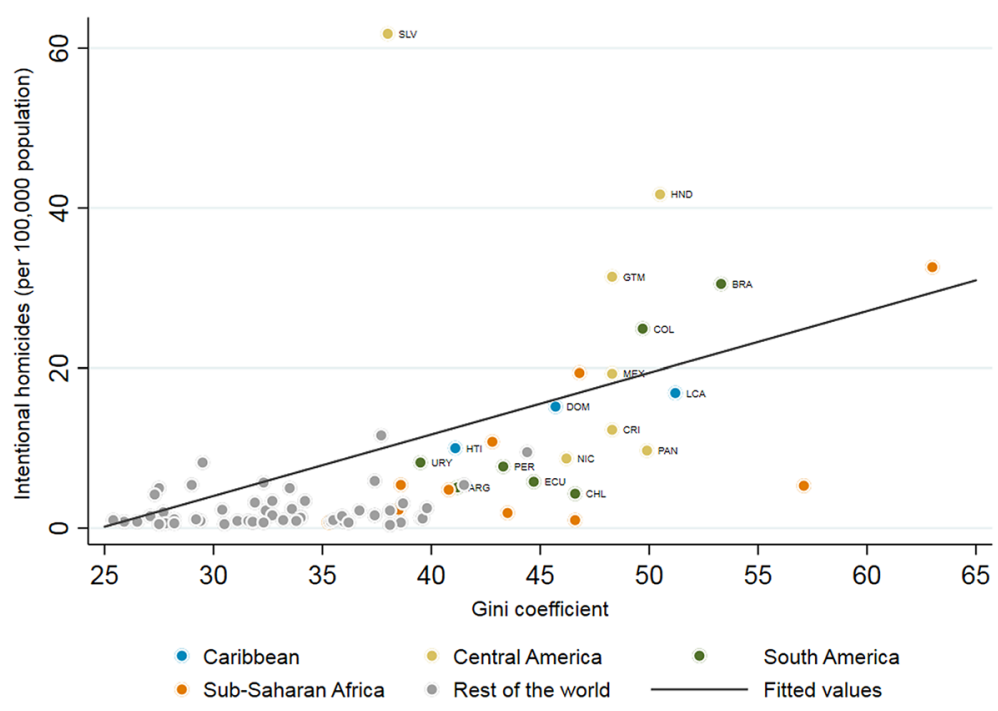

Fig. 5 Homicide rates and inequality based on the Gini index, 2017 or latest year available (Source: Produced by the author based on UNODC and World Bank database)

those of countries with similar or higher levels of inequality. Thus, the region is also an outlier in this dimension.

Given the statistics discussed above, it is not surprising that the main concern of the people of Latin America and the Caribbean is crime, even above unemployment or their economic situation. One in four citizens in the region states that crime is the main problem in their country (Latinobarómetro 2017).

In this setting, crime leads to costly behavioral responses to mitigate the risk of victimization and to cope with the pain and suffering. These costs may include the loss of productive life years, the break-up of families, the loss of social capital, the undermining of public trust, deterrence of investment, capital flight, brain drain, internal displacement, and a general loss of confidence in democracy.

On average, it is estimated that crime imposes significant costs on the Latin American and Caribbean economies, absorbing at least 3.55\% of GDP (Jaitman 2017). This is equivalent to what the region spends annually on infrastructure, or roughly equal to the income share of the poorest $20 \%$ of the population in the region. This estimate is performed using the accounting method to allow for comparisons between countries. The methodology includes private spending on security (firms and households), public spending on security (police, prison administration, and criminal justice expenditures), and the social cost of crime (forgone income of victims of violent crime, mainly homicides, and forgone income of those in prison). Figure 6 shows the weight of each of these factors in the cost of crime. Although this estimate is conservative, as it does not include most of the indirect and intangible costs of crime, it provides a clear picture of the impact of crime and violence and the potential welfare gains that would come from reducing it.

Are these costs large from an international perspective? Figure 7 compares the costs of crime in Latin America and the Caribbean with those of a set of developed 


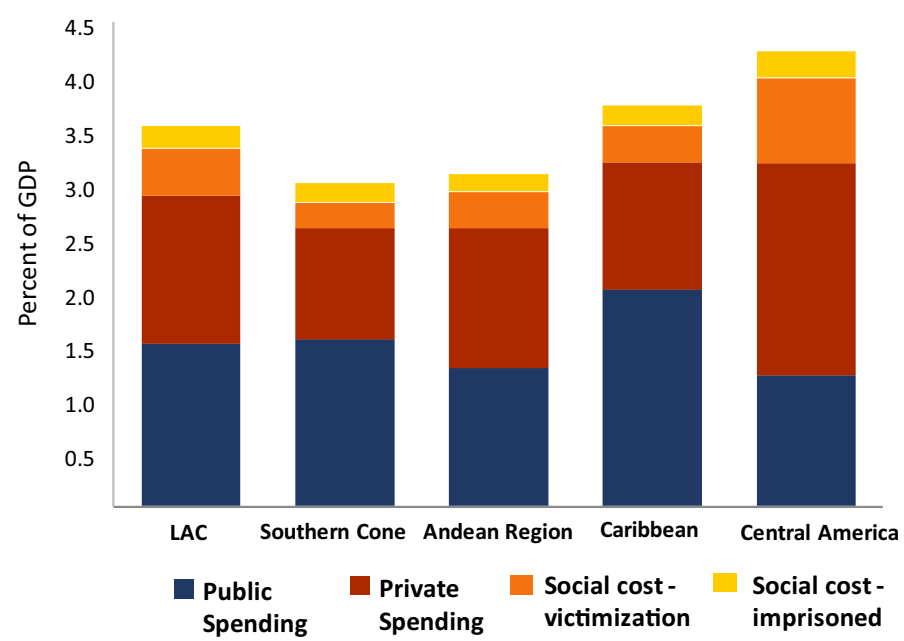

Fig. 6 Overall crime-related costs, by Latin American and Caribbean subregion, 2014 (percent of GDP) (Source: Jaitman (2017))

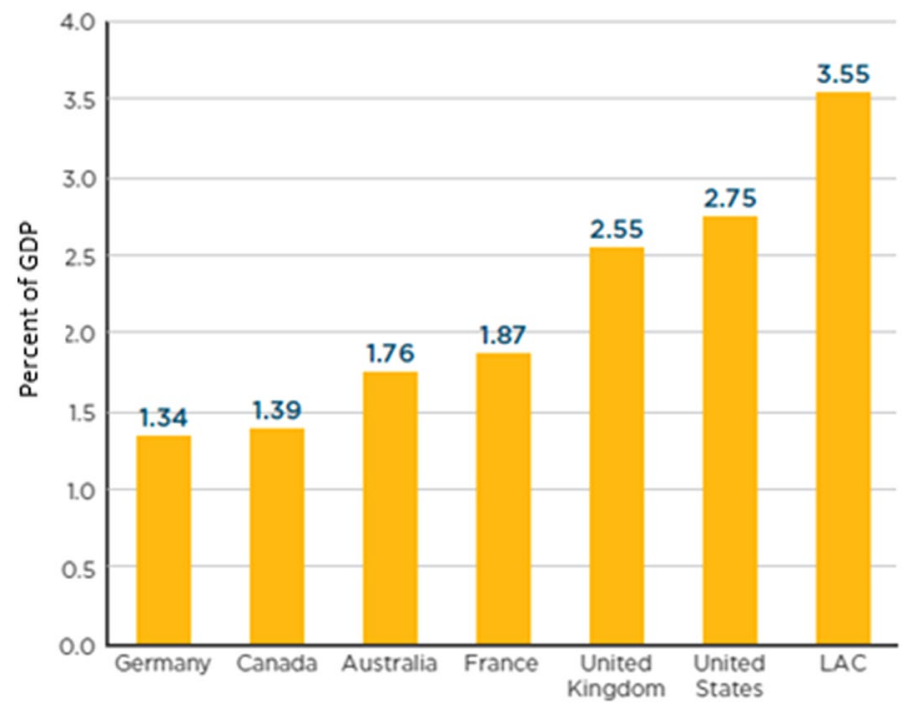

Fig. 7 International comparison of mean crime-related costs. LAC Latin America and the Caribbean (Source: Jaitman (2017))

countries-Australia, Canada, France, Germany, the United Kingdom, and the United States. The cost of crime in Latin America and the Caribbean is twice the average cost in developed countries. Public spending on security is comparable to developed countries-the main differences are mainly in the social costs of crime.

To cope with crime, there has been an increase in public spending on security in recent years in Latin America and the Caribbean. Law enforcement agencies have become larger, with personnel added to police forces. However, the results in many countries or cities have not been what was expected, which points to the importance 
of understanding the causes of crime and measuring the effect of different crime prevention and crime control policies to make efficient spending decisions.

Crime economics provides a useful framework to assess the different policies and to discuss the incentives to commit crime in a more pragmatic and less ideological manner, as is the usual case in the region.

\section{A framework of crime and economics}

The aforementioned seminal crime economics paper by Gary Becker presents a model in which rational individuals decide whether or not to commit a crime (Becker 1968). This choice is made under circumstances of uncertainty, so it is based on the expected return of the criminal activity and on the probability of being punished. This section describes the baseline static model in detail and incorporates recent extensions to make it dynamic in light of Chalfin and McCrary (2017) and Lee and McCrary (2009).

In Becker's model, individuals who decide to engage in criminal activities in a given period receive a criminal benefit, but they also face the risk, $p$, of being caught and punished. Individuals who decide not to commit a crime do not receive any return from criminal activities, but this choice is risk-free. Consequently, individuals decide to commit a crime if, and only if, the expected utility of engaging in criminal activity in each period $t$ is higher than the expected utility of not committing a crime, as stated below:

$$
p U^{\mathrm{cp}}+(1-p) U^{\mathrm{c}}>U^{\mathrm{nc}}
$$

where $U^{\mathrm{cP}}$ is the utility of committing a criminal activity and being punished, $U^{\mathrm{c}}$ is the utility of committing a criminal activity and not being punished, and $U^{\mathrm{nc}}$ is the utility of not committing a crime. It is assumed that the utility of a criminal activity is higher than that of a legal activity if not caught and punished: $U^{\mathrm{c}}>U^{\mathrm{nc}}>U^{\mathrm{cp}}$.

The utilities in Eq. (1) are functions of many factors related to individual and market characteristics. The utility associated with the decision to not commit a crime $\left(U^{\mathrm{nc}}\right)$ is a function of the individual ability to derive utility from legal activities, such as the wage that the individual can earn in the legal labor market (which in turn depends on other variables like education). As this wage increases, criminal activities become less attractive, since the benefit of crime is reduced relative to the wage, keeping the probability $p$ of being punished constant.

The decision to commit a crime is not only a function of the probability of being caught and punished, but also a function of the disutility associated with the punishment. Becker (1968) represents this disutility with an exogenous variable, $f$, which can be understood as the severity of the punishment, a fine, or other factors that affect the prospective criminal if punished, such as unpleasant prison conditions. It is important to note that preventing crime is costly (requires public spending on security, for example on police personnel, judiciary, and prisons). Therefore, the optimal crime rate in the economy is likely higher than zero as we have to take into account the cost-benefit relation of additional resources allocated to prevent crime.

The expected utility of criminal activities in each period can be expressed by: 


$$
E(U)=p U(Y-f)+(1-p) U(Y)
$$

where $Y$ represents the income associated with earnings from crime and $U($.$) is a utility$ function, with standard properties. As before, an individual decides to engage in criminal activities if, and only if, $E(U)>U^{\mathrm{nc}}$, and is indifferent if $E(U)=U^{\mathrm{nc}}$. This occurs at point $Y^{*}$, which can be interpreted as the reservation income from criminal activities. Alternatively, the individual decides to commit a crime if, and only if, $Y>Y^{*}$.

The indifference condition can also be expressed by the equation below:

$$
\frac{U\left(Y^{*}\right)-U^{\mathrm{nc}}}{U^{\mathrm{nc}}-U\left(Y^{*}-f\right)}=\frac{p}{1-p} .
$$

Equation (3) highlights that the gain of engaging in criminal activities and not being caught relative to the loss of engaging in criminal activities and being caught is equal to the ratio of the probabilities of being punished or not. This equation also shows that an increase in $p$ reduces the likelihood of crime, since it requires that the gain from committing a crime relative to its loss be even higher. Finally, from Eq. (3), it is straightforward that an increase in $f$ reduces the likelihood of crime, since $U^{\prime}()>$.0 . In other words, an increase in $f$ leads to a decrease in the gain from committing a crime relative to its loss.

Under risk neutrality, one can simplify this static model defining $a$ as the income associated with abstaining from crime, i.e., $U^{\mathrm{nc}}=U(a)$, and $c$ as the effective cost of punishment, $c=f-b>0$, where $b$ is the criminal benefit and $b^{*}$ is the criminal benefit that makes the individual indifferent as to whether or not to commit or not commit a crime, i.e., $Y=a+b$ and $Y^{*}=a+b^{*}$. Then, Eq. (3) can be rewritten as

$$
b^{*}=c \frac{p}{1-p} .
$$

This simplified version of the Becker model is the starting point of the dynamic analysis in Lee and McCrary (2009). This is an important contribution because many features of crime and law enforcement are dynamic in nature. Intuitively, Lee and McCrary (2009) suggest that it would be hard to deter an impatient individual by way of a prison sentence $(f)$, since most of the disutility of a prison sentence is borne in the future. For instance, violent crimes are usually punished by lengthy prison sentences rather than fines. Thus, the disutility associated with apprehension is experienced many periods after the utility gain associated with commitment of the crime. The time horizon of the offender especially relevant for Latin America and the Caribbean, as the sentences in the event of apprehension and trial are usually long as the level of violence, is high in the region and equated with that of an epidemic by international standards (see Sect. 2).

To introduce the stochastic element in this model, it is assumed that in each period $t$ the individual is free, receives a random draw $(B)$ from a distribution of criminal opportunities, and chooses to commit a crime or to engage in legal activities (abstain). These opportunities are a function of $p$, and their attractiveness depends negatively on the value of $p$, i.e., the opportunity is more attractive when the probability of being caught is lower. The cumulative distribution of criminal opportunities is $F_{t}(b)$ and the density $f_{t}(b)$. 
The individual who decides to abstain from criminal activity receives a flow utility $U_{t}=a$. The individual who decides to offend in period $t$ receives a flow utility $U_{t}=a+B$ if he or she is not caught. But with probability $p$, the individual can be caught, and in this case, will be incarcerated for the next $S$ periods and have a flow utility of $U_{t}, U_{t+1}, \ldots, U_{t+S-1}=a-c . S$ is a random draw from the distribution given by the probabilities $\left\{\pi_{S}\right\}_{S=1}^{\infty}$. The individual chooses to offend or abstain in each period to maximize $E_{t}\left[\sum_{\tau=t}^{\infty} \delta^{\tau-t} u_{t}\right]$, where $\delta$ is the discount factor.

The Bellman equation of this problem is:

$$
V(b)=\max \left\{a+\delta E[V(B)], p \sum_{s=1}^{\infty} \pi_{s}\left[(a-c) \frac{1-\delta^{s}}{1-\delta}+\delta^{s} E[V(B)]\right]+(1-p)[a+b+\delta E[B(b)]]\right\} .
$$

The first argument is the payoff of not committing a crime and the second is the expected payoff from committing a crime. Individuals will commit a crime when the crime benefit exceeds the "reservation" benefit, i.e., when $B>b^{*}$, and will abstain when $B<b^{*}$. At $b^{*}$, the individual is indifferent as to whether or not to commit a crime and, at this point, the two arguments of the max function are equal. The reservation benefit can be expressed as:

$$
b^{*}=c \frac{p}{1-p}\left[1+\sum_{s=1}^{\infty} \pi_{s} \frac{\delta-\delta^{s}}{1-\delta}\left(1+\frac{(1-\delta) E[V(B)]-a}{c}\right)\right] .
$$

From the expression above, Lee and McCrary (2009) make several observations. First, when $\delta=0, b^{*}=c \frac{p}{1-p}$. This means that crime will be committed whenever the ratio of the net benefit to net cost, $\frac{B}{c}$, equals the ratio of the probabilities of being punished or not. This result is exactly the same as before: crime is reduced by increases in $p$ and increases in $c$. To the extent that the discount factor approaches zero, the individual is arbitrarily more responsive to capture than to punishment. Second, the result of the static model also holds if the punishment period is one period long. Third, the crime rate decreases with a higher discount factor, $\delta$. Fourth, the added feature of this model is that crime is also reduced by increases in sentence lengths, and this behavioral mechanism operates through time preferences. In sum, the framework proposed by Lee and McCrary (2009) re-introduces in a simple way important ideas regarding the importance of celerity into a Becker model.

\section{The Frontiers of knowledge in crime economics and their relevance for Latin America and the Caribbean}

This section provides an analysis of the state of the art in crime economics research, not only to identify critical knowledge gaps in the literature but also to contribute to the dissemination of evidence-based crime reduction and prevention strategies. The aim is to provide a solid starting point to take stock of the lessons learned that can be relevant for Latin America and the Caribbean, and to determine what the priorities should be considered for future research. To limit the scope of the review, a critical inclusion criterion was that an evaluation must have a control or comparison group for causal inference of a crime-and-violence-related outcome. Random assignment studies have been highlighted, but solid quasi-experimental analyses are also incorporated. Also, it is important 
to note that the crimes studied are related to interpersonal violence, and we exclude other types of crime that are important in the region, such as corruption.

Under the setup developed in Sect. 3, high crime rates in Latin America and the Caribbean are a consequence of higher expected net benefits from illegal activities for prospective criminals. This is due to a low expected return to education or legal jobs $\left(U^{\mathrm{nc}}\right)$, or to a low expected cost of committing crimes $\left(U^{\mathrm{c}}\right.$ and $\left.U^{\mathrm{cP}}\right)$, or most likely to a combination of both factors.

Most of the empirical literature on crime economics has focused on interventions that may increase the expected cost of committing crimes, and thus have a deterrent effect on prospective criminals. There are three main concepts of the deterrence theory: the certainty, severity, and (less studied) celerity of punishment which prove to be important in a dynamic theoretical crime economics model. Certainty refers to the probability of legal sanctions given the commission of a crime $(p)$; severity refers to the onerousness of the sanction imposed $(f)$ and the sentence length; and celerity refers to the lapse in time between the commission of a crime and its punishment (Nagin 2013).

The section of this paper on the police focuses on the certainty and celerity of punishment, while the imprisonment section focuses on the severity of punishment. The imprisonment section also analyzes re-insertion and rehabilitation programs that aim to improve the situation of inmates when they are released and position them to have better opportunities in the legal job market, thus reducing recidivism.

There are also interventions that may increase the expected net benefit of legal activities. These interventions that aim at the social prevention of crime and violence are supposed to increase the payoff of legal activities, thus making crime less attractive. In the case of social prevention targeting youth, a training or employability program would increase the possibilities of labor market attachment and, thus, potential earnings in the legal sector, ultimately reducing crime.

\subsection{Increasing the expected cost of committing crimes}

\subsubsection{Police and crime}

Under the setup of Sect. 3, the amount of crime will respond the probability that an individual is apprehended after having committed a particular offense $(p)$. This probability may depend on the society's investment in a police presence, and whether that presence is operationalized through increased manpower or increased productivity. To the extent that potential offenders are able to observe an increase in police resources and perceive a correspondingly higher risk to criminal participation $(p)$, crime is expected to decline through the deterrence channel. This section analyzes the responsiveness of crime to both police size and police strategies. For the literature on each of those two topics, the challenges will be discussed with respect to both econometric identification and the interpretation of the results as evidence in favor of deterrence.

With regard to the effect of police size on crime, the identification problem arises from the fact that areas with higher crime rates usually by definition have more police presence. Therefore, when regressing the crime rates on police force size variables using a cross-sectional approach, there is an omitted variable bias. There has been a growing body of literature using quasi-experiments or natural experiments to overcome the 
endogeneity problem of causal inference in assessing the effect of police force size on crime.

The seminal paper of Levitt (1997) is the first quasi-experimental paper to use instrumental variables to identify the causal effect of police size on crime. Levitt (1997) uses mayoral elections as an instrument, while Levitt (2002) uses the number of firefighters. Evans and Owens (2007) exploit the variation in the timing and size of grants provided by the Community Oriented Policing Services Program in the United States to examine the relationship between police force size and crime. Each of the studies mentioned in this paragraph finds different magnitudes of the police size effect on crimes such as robbery, burglary, auto theft, and aggravated assault. Moreover, McCrary (2002) re-estimates the instrumental variables coefficients in Levitt (1997), which were not significant with a weighting correction.

The other strand of research on the relationship of police force sizes to crime is the exploitation of natural experiments relating to exogenous shocks to police presence in very particular settings, such as a response to terrorist attacks. Di Tella and Schargrodsky (2004) study the deployment of police officers in Jewish institutions after a terrorist attack on the main Jewish administrative building in Buenos Aires, Argentina. They find that car thefts fell by $75 \%$ in the blocks in which the protected institutions are situated. However, the effect is local, with no appreciable impact outside the narrow area where the police are deployed. A similar identification strategy was used by Draca et al. (2011) to analyze the deployment of police officers in London after the terror attacks of July 2005. They find that the extra presence of police reduces what they refer to as susceptible crimes (i.e., those that are more likely to be prevented by police visibility). Specifically, a $10 \%$ increase in police activity reduces susceptible crimes by 3 to $4 \%$. Klick and Tabarrok (2005) use terror alert levels in Washington, DC to make inferences about the crimepolice relationship. They show that an increase in police presence by about $50 \%$ leads to a statistically significant decrease in the level of crime on the order of $15 \%$. Cohen and Ludwig (2003) exploit short-term variation in the intensity of police patrols by day of the week in several different patrol areas in Pittsburgh, Pennsylvania. They find that shootings were considerably lower in areas and on days that received more intensive police patrols.

In relation to the long-term consequences of patterns of police deployments, MacDonald et al. (2016) use a spatial regression discontinuity design to study the impact of especially intensive policing around the University of Pennsylvania. While areas adjacent to the university received police patrols from both the university and municipal police, areas slightly further away received only municipal police patrols. Results show that street crimes were substantially higher in the blocks just outside the area patrolled by the university police relative to the blocks just inside the university patrol area.

In sum, the review by Chalfin and McCrary (2017) highlights that the magnitude of the impact of the elasticity of police on crime varies between studies, and cross-crime elasticities generally favor a larger effect of police on violent crimes than on property crimes, with especially large effects of police presence on murder, robbery, and motor vehicle theft. 
There is also literature on the effect of different policing strategies on crime. The literature on police deployments and tactics has focused predominantly on three types of interventions: hot spot policing, problem-oriented policing, and proactive policing.

4.1.1.1 Hot spot policing Hot spot policing describes a strategy in which police are disproportionately deployed to areas in a city where there are disproportionate levels of crime. The first-order question that the hot spot policing literature seeks to address is the degree to which highly localized crime is responsive to a change in the intensity of policing. Various evaluations of such interventions suggest a statistically significant decrease in crime, non-significant spatial displacement, and some evidence of diffusion of benefits (Bowers et al. 2011). Sherman and Weisburd (1995), Telep et al. (2012) and Ratcliffe et al. (2011) exploit randomized control design where treated hot spots are exposed to more police patrols. Each study finds that the treated areas with more police presence experienced less calls for services relative to calls in control hot spots. Indeed, a review of the literature by Braga (2001) identified nine experiments or quasi-experiments involving hot spot policing and noted that seven of the nine studies, including a majority of the randomized experiments, found evidence of significant and large reductions in crime.

Most of the literature finds no evidence of displacement of crime to adjacent neighborhoods as a result of hot spot policing, and a number of studies find that the opposite is true-that there tends to be a diffusion of benefits to non-treated adjacent locations (Sherman and Rogan 1995; Braga 2007; Braga et al. 1999; Caeti et al. 1999).

Hot spot policing might be an even more important and effective strategy in Latin America, as it relies on deterrence rather than incapacitation, given the very low clearance rates for many crimes. Alves and Arias (2012) use a time series design to evaluate the Fico Vivo hot spot program that originally targeted a poor neighborhood in Belo Horizonte, Brazil with very high homicide rates. Results show that the program had significant success in reducing homicides.

4.1.1.2 Problem-oriented policing A promising approach for dealing with crime hot spots is having officers who incorporate principles of problem-oriented policing, which involves organizing residents and property owners to help the police identify the sources of violent and property crime, and then targeting these problems with focused deterrence-based warnings to repeat offenders, more police, citizen, and technological monitoring, and better control of physical and social disorders (Nagin 2013). These activities usually involve joint action with police, prosecutors, and even the community.

One of the most well-known evaluations of a problem-oriented policing approach is that of Boston's Operation Ceasefire by Kennedy et al. (2001). The stated purpose of Operation Ceasefire was to reduce youth gun violence in Boston. The intervention involved a multifaceted approach and included efforts to disrupt the supply of illegal weapons in Massachusetts. It also included messages communicated by police directly to gang members that authorities would use every available "lever" to punish gangs collectively for violent acts committed by individual gang members. In particular, the police indicated that the stringency of drug enforcement would hinge on the degree to which gangs used violence to settle business disputes. The result of the 
intervention was that youth violence fell considerably in Boston relative to other U.S. cities included in the study.

Since Operation Ceasefire, the strategy of "pulling every lever" has been the centerpiece of field interventions in many U.S. cities, including Richmond, Virginia, Chicago, Illinois, Stockton, California, High Point, North Carolina, and Pittsburgh, Pennsylvania (see Kennedy 2006). The focus of the approach, based on deterrence theory, is that the responses be certain, severe, and swift. A 2012 review of the literature by Braga and Weisburd suggests that the strategy of pulling every lever has been effective in reducing serious violent crime, with all reviewed studies finding negative point estimates, most of which were significant (Braga and Weisburd 2012).

With respect to individual evaluations, reductions in crime have been found across U.S. cities. For instance, Braga and Bond (2008) conducted a randomized controlled trial to examine the effects of problem-oriented policing strategies in reducing crime and disorder problems in hot spots in Lowell, Massachusetts. Only the treatment group received problem-oriented policing. The authors found that the treated hot spots experienced statistically significant reductions in total calls for service, as well as varying reductions in all subcategories of crimes, relative to controls. In turn, Taylor et al. (2011) conducted the first randomized experimental study that compared different treatments to hot spots in Jacksonville, Florida. Results showed there was no significant crime decline in the problem-oriented policing hot spots during the intervention period, although in the 90 days after the experiment, street violence declined by a statistically significant $33 \%$.

In sum, evaluations of pulling all lever strategies show promising results. Nevertheless, inference is invariably complicated by a lack of randomized experiments and the inherent difficulty of identifying appropriate comparison cities and by the small sample sizes, among other problems. Therefore, caution is needed in assessing this literature and it would be important to explore these policies further in other regions such as Latin America and the Caribbean.

4.1.1.3 Proactive policing Finally, proactive policing refers to the police tactics literature in criminology that investigates the responsiveness of crime to the intensity of policing, holding resources constant.

One strand of such police tactics is predictive policing, which investigates the use of information and advanced analysis to inform forward-thinking crime prevention. Predictive methods do not predict where and when the next crime will be committed. Rather, they predict the relative level of risk that a crime will be associated with a particular time and place (Perry et al. 2013).

The potential of predictive policing to reduce crime relies on the fact that crime does not randomly disperse across a geographic area. Instead, crime is clustered in particular areas that usually can be explained as a function of certain factors that create vulnerabilities for victims at certain places and times (Weisburd 2015; Chainey et al. 2008). According to previous studies in the developed world, crime tends to cluster geographically (Eck and Weisburd 1995; Evans and Herbert 1989; Felson 1987; Gil et al. 2017; Pierce et al. 1988; Weisburd and Green 1994), and crime indeed tends to be repeated in 
time and space (Johnson et al. 2007). A main finding on crime and place is what Weisburd (2015) posits as a general "law of crime concentration at place".

Different theories have been posited for why concentration of criminal activity occurs. The recognition that the risk of crime increases because of identifiable factors has clear implications for predictive policing. If police can identify the location of potential crimes and understand the relevant factors for those predicted crimes, then they can focus their resources on those locations.

Although there has been a surge of interest in predictive policing in recent years, there is limited rigorous empirical evidence to date on whether it has more of an impact on crime than other policing strategies (Bennett et al. 2016). Current empirical evidence refers mainly to experiences with property crimes in the United States. Moreover, only a few studies have used rigorous methods to assess the impact of predictive policing on crime that can establish a causal link between the use of predictive policing technologies and changes in crime.

Regarding this line of study, Mohler et al. (2015) conducted two controlled randomized experiments using an epidemic-type aftershock sequence model (ETAS) that estimates the risk associated with both long-term hot spots and short-term models of near-repeat risk involving the Los Angeles Police Department and the Kent Police Department (United Kingdom). In the experiments, the ETAS algorithm (treatment) was compared with hot spot maps produced each day and each shift by dedicated crime analysts (control). Because hot spot locations dynamically changed each day, an experimental design was used in which days were randomly assigned to treatment or control. The experiment focused on burglary, car theft, burglary theft from a vehicle, criminal damage, violence against a person (including sexual offenses), and robbery. Police patrols using ETAS forecasts led to an average $7.4 \%$ reduction in crime volume as a function of patrol time, whereas patrols based on analyst predictions showed no significant effect.

On the other hand, Hunt, Saunders, and Hollywood (2014), using a blocked randomized approach, found no statistical evidence that crime was reduced more in experimental districts that used predictive policing models than in control districts that relied on traditional crime analysis. This experiment, conducted in the Shreveport Police Department in Louisiana, aimed to evaluate the policing strategy known as Pilot that developed a prediction and prevention model to reduce residential, auto-related, and business property crimes. Specifically, district pairs were randomly assigned to treatment and control groups. Treated districts were given maps that highlighted blocks predicted to be at higher risk of property crime. To generate predictions of future property crimes, the Shreveport Police Department performed multivariate logistic regression analysis for grid cells $(400 \times 400$ feet $)$ covering each treatment district. These districts were also provided with overtime resources to conduct special operations. Control districts also conducted property-crime-related special operations using overtime resources, but just targeting areas that had recently seen property crimes. Hence, the principal difference for control districts was that special operations targeted small areas where clusters of property crimes had already occurred-that is, hot spots were derived from conventional crime mapping techniques rather than from a predictive model. Results showed no statistical evidence that crime was reduced more in experimental districts than in control districts. However, several factors that might explain the overall null effect were 
identified, including low statistical power, program implementation failure, and program theory failure.

Recently, the shift from predicting and ranking "hot spots" to "hot people" has become a new focus for predictive policing (Ferguson 2016). For example, Saunders et al. (2016) evaluated the impact of a predictive policing program on gun violence based on a list of people estimated to be at the highest risk of gun violence, who were then referred for a preventive intervention. In addition, Mastrobuoni (2017) analyzed the effect of an offender-based software in Italy. Both find reductions on crime.

Using a quasi-experimental study, Kennedy et al. (2011) examined the use of risk terrain modeling, a predictive crime analytic approach. This study compares street segments and intersections that received police proactivity using results of risk terrain modeling with control segments derived from propensity score matching that did not receive extra police effort. The study found positive effects on crime rates. However, since control segments did not receive targeted patrols, it is still unanswered whether it was the technology or the targeted patrols that caused the reduction in crime.

The "law of crime concentration at place" also holds for a sample of Latin American cities. For example, Galiani and Jaitman (2016) analyze the performance of predictive policing in Uruguay. They conducted a randomized control trial to compare the predictive software with the status quo predictions developed by the police department and found no statistically significant differences for robberies between the police precincts randomly assigned to the crime analysts' predictions and those assigned to the predictive policing software.

As can be noted, there are insufficient robust empirical studies to draw conclusions about the efficacy of crime prediction software. This has been recognized in the last report of the National Academies of Sciences, Engineering, and Medicine (2018). In addition, relatively little evidence-based knowledge exists about whether and to what extent predictive policing techniques will have crime prevention benefits at larger jurisdictional levels or across all offenders, and whether those benefits will continue over the long term (National Academies of Sciences, Engineering, and Medicine 2018). Thus, there is a need to more deeply understand how technology affects police agencies and, in turn, reduce crime. This is especially true for Latin America and the Caribbean, where, for instance, information software, such as predictive policing, is scarce but has a high penetration mainly from foreigner companies. Some countries in the region such as Chile are using predictive software developed in the country by researchers joint with the government (Baloian et al. 2017). It will be important to do research in their effectiveness to reduce crime in the region.

A second focus of the literature has been on the advent of what is called "broken-windows policing," also known as "order maintenance" or "disorder" policing (Wilson and Kelling 1982). This strategy is based on strict enforcement by the police of laws governing relatively minor infractions, such as vandalism and turnstile jumping. Following the framework of Sect. 3, broken-windows policing operates primarily through perceptual deterrence. If offenders observe that police are especially vigilant, they may update their perceived probability of apprehension for a more serious crime, and accordingly they will decrease their participation in crime $(p)$. 
The literature that assesses the impact of broken-windows policing on crime has focused mainly on the case of New York City, which experienced the largest decline in crime among major U.S. cities. Most of the research presents identification problems, and although these problems can be set aside, it is unclear that this literature can isolate the impact of broken-windows policing from other changes that drove crime down in New York City (Chalfin and McCrary 2017).

Three studies that used especially strong research designs are worth mentioning. First, Braga et al. (1999) provide the first experimental evidence of a strategy aimed at addressing disorder. In Jersey City, New Jersey, 12 of 24 crime hot spots were randomly assigned to receive an intervention that involved broken-windows policing as well as other placespecific treatments that were intended to reduce crime. Results show significant crime reduction in treated locations. Second, Braga and Bond (2008) randomly assigned a general broken-windows policing strategy to 17 hot spots. They found strong reductions in crime in treated areas, but evidence of an effect of misdemeanor arrests was far more limited. Third, Caetano and Maheshri (2014) use an identification strategy that leverages highly detailed micro-data of all reported crimes and police response to these crimes in Dallas, Texas from 2000 to 2008. The identification strategy isolates the causal behavioral effect of prior crimes on future crimes and is robust to a variety of sources of endogeneity. They find no evidence of an effect of "zero tolerance" law enforcement policies on crime using micro-data from police precincts.

Finally, a systematic review conducted by Weisburd (2015) of studies that use experimental or quasi-experimental design or a before-after assessment of outcomes finds a slightly negative, albeit statistically not significant, impact.

In all, the evidence suggests mixed results. More research is needed, preferably based on experimental or quasi-experimental evidence, to support or refute any clear impact.

In sum, this section has reviewed a large literature on the responsiveness of crime to police size and tactics. Some key conclusions are worth noting. First, there is robust evidence that crime responds to increases in police manpower and to many varieties of police redeployments. However, it is necessary to further study the effect on long-term outcomes. It is necessary to better understand which interventions are cost-effective and how strategies can be maximized to improve the relationships between the police and the public, especially in Latin America and the Caribbean.

\subsubsection{Incarceration and the severity of punishment}

The prison rate in Latin America and the Caribbean is on the rise. This is clear in a simple comparison. In the United States, imprisonment increased 19\% between 1995 and 2012, from 595 to 709 inmates per 100,000 population. In the same period, crime was significantly reduced: the homicide rate fell from 8 per 100,000 population to 5 per 100,000 population. In Latin America and the Caribbean, the opposite occurred. While the prison population also exponentially increased between 1995 and 2012 from 101.2 to 218.5 inmates per 100,000 population, an increase of $116 \%$, crime also increased further during this period, with regional homicide rates doubling from 13 to 26 homicides per 100,000 inhabitants. 
This section is focused on deterrence (i.e., emphasis on the negative consequences of delinquent behavior), incapacitation (i.e., emphasis on preventing at-risk individuals from becoming involved in delinquent activities), discipline (i.e., imposition of a rigorous regime to avoid re-offending), and rehabilitation (i.e., counseling, therapy, skill-building and re-entry programs to change the attitudes and behavior of prisoners).

According to the conceptual framework in Sect. 3, these interventions can be effective because they (1) raise the expected cost of lawless behavior by increasing the probability of authorities detecting such behavior $(p)$, as well as the severity of the punishment once caught $(f)$ that also enters through lengthier sanctions in the dynamic model; (2) change cognitive processes, as well as the capacity for self-control and empathy, reducing the expected gains of delinquency; and (3) make individuals more educated and employable, thus increasing the quantity and quality of legitimate opportunities and reducing the opportunity cost of deviant behavior $\left(U^{\mathrm{nc}}\right)$.

4.1.2.1 Deterrence The effectiveness of deterrence has been repeatedly validated empirically. Under the setup of the model in Sect. 2, a dynamic perspective of deterrence is essential: if offenders have short time horizons, then it is hard to imagine punishment acting as an important deterrent. This is highly relevant because serious crimes are usually punished by long prison sentences, measured in years or even decades.

Evidence suggests that longer sentences seem to be effective in preventing crime. For instance, Philippe (2013) studies a shift in the instantaneous probability of re-offense when offenders are threatened with longer sentences and finds a decline in the hazard rate of re-offense of approximately 5\%. Drago et al. (2009) assess the impact of an increase in sentence time in the context of the large Italian amnesty of 2006 and estimate that when expected sentences are increased by $25 \%$, the propensity to re-offend in seven months decreases by approximately $18 \%$. Bell et al. (2014) show that significant increases in sentencing severity, induced by the London riots of August 2011, led to a 13\% decline in riot crimes in non-riot sub-wards. Lee and McCrary (2009), however, exploit the fact that young offenders are legally treated as adults (and face longer lengths of incarceration) the day they turn 18 and estimate an elasticity of crime with respect to sentence lengths of only about -0.05 .

The possible anti-crime effect of incarceration acts in two concrete ways: it can deter crime by making it less attractive because of the harsher sanctions $\left(U^{\mathrm{cP}}\right)$, and it can reduce crime through the "incapacitation" effect, since (in theory) incarcerated criminals are isolated from the illegal labor market.

4.1.2.2 Incapacitation The effect of incapacitation on incarceration and recidivism is well documented in the literature. Owens (2009) exploits a 2001 change in Maryland's sentencing guidelines that reduced the sentences of 23-, 24-, and 25-year olds with juvenile delinquent records by a mean of 222 days to estimate the effect of sentence length on recidivism. She shows that former delinquents between the ages of 23 and 25 would have been involved in 1.4-2.9 index crimes per person each year had they not been incarcerated. Vollaard (2013) exploits a legislative change that extends a criminal's prison term tenfold in the Netherlands, and concludes that even when only $5 \%$ of the prison population was sentenced under the law 6 years after its introduction, the rate of theft declined 
on average by $25 \%$, and by as much as $40 \%$. Buonanno and Raphael (2013) in a different setting in Italy finds a sizable incapacitation effects mainly for the crimes of theft and robbery ranging from 17 to 21 crimes per prison year served. They exploit a natural experiment that affected incarceration. In August 2006, the Italian government released more than one-third of the nation's prison inmates in an attempt to relieve prison overcrowding. The collective pardon did not change sentencing for future offenders while it enhanced sentences for pardoned offenders who reoffend. These changes likely induced a modest deterrent effect on criminal activity. Thus, the effects they find on crime associated with the pardon reflect a lower-bound incapacitation effect estimate.

Nevertheless, certain factors may favor the criminogenic effects of prisons: high overcrowding rates (occupancy on average is almost double the availability of places), deficiencies in rehabilitation services and re-insertion of prisoners (including the inability to analyze the level of risk posed by prisoners and treat them accordingly), and high rates of prisoners without conviction. For instance, Drago et al. (2011), based on variation in prison assignment, suggest that the prison environment is criminogenic; that is, harsh prison conditions actually increase post-release criminal activity in Italy. By exploiting a discontinuity in the assignment of federal prisoners to security levels in the United States, Chen and Shapiro (2007) arrive at the same conclusion. Gaes and Camp (2009) show that when offenders are placed into higher-than-necessary levels of security, they are more likely to have higher rates of recidivism than if they were placed at the appropriate security level. Finally, in a study of framing effects, by exploiting a legal change in Maryland that altered recommended but not actual sentences for a subset of offenders, Bushway and Owens (2013) find that criminals who receive a large reduction in their sentence may internalize the notion that the criminal justice system is lenient and be less deterred in the future.

4.1.2.3 Discipline Programs based mainly on fear, shock, incarceration, punishment, or military discipline has surprisingly been the subject of negligible empirical research. What scarce literature does exist on this approach reveals no appreciable impact on recidivism.

The archetypical model for juvenile awareness is the Scared Straight intervention in the United States, which attempts to deter youths from delinquent behavior by terrifying them about prison life. In a review of studies that randomly assigned delinquents into control or intervention (Scare Straight) groups, Petrosino et al. (2003) show that in no case was there a decline in recidivism in the treated group. Furthermore, treated delinquents were in fact up to $28 \%$ more likely to recidivate than those in the control groups. However, the authors suggest taking these results with a degree of caution given potential methodological limitations. Aizer and Doyle (2015) find that imprisonment as a punishment for youths leads to a higher probability of adult incarceration.

Experimental impact evaluations of three boot camp programs in Cleveland, Ohio, Denver, Colorado, and Mobile, Alabama by the U.S. Department of Justice's Office of Juvenile Justice and Delinquency Prevention found little support for this sort of intervention. While the recidivism rate in the control group was $50 \%, 72 \%$ of treated inmates in Cleveland's boot camp recidivated. In Denver and Mobile, rates of recidivism were found to be comparable in the experimental and control groups (39\% vs. $36 \%$, and $28 \%$ vs. $31 \%$, in the respective cities) (Peters 1996a, b; Thomas and Peters 1996). Based on a 
quasi-experimental design, Zhang (2000) evaluated a juvenile boot camp in Los Angeles that, unlike most military discipline interventions, includes an aftercare component combined with intensive supervision and counseling. The author shows that boot camp graduates exhibited almost identical recidivism outcomes to inmates in the comparison group. Furthermore, boot camp participants were more likely to have probation revocations. Wells et al. (2006) compared the recidivism of juveniles who completed a shock incarceration program that included a systematic aftercare phase with a matched comparison group of youths released from traditional residential placements. They found no differences in reconvictions or the seriousness of re-offenses at 8- or 12-month follow-ups.

Some governments in developed and developing countries have considered re-implementing military conscription as a policy mechanism to reduce violence among youth. However, exploiting the random assignment of young men to conscription in Argentina through a draft lottery, Galiani et al. (2011) show that compulsory enlistment into the armed forces actually increases the likelihood of developing a criminal record. The authors do not necessarily suggest this is the result of deleterious behavioral changes induced by extremely regimented activities, but rather they attribute this effect to reduced entry costs into crime caused by firearm training received during military service, as well as lost employment opportunities resulting from delayed insertion into the labor market.

4.1.2.4 Rehabilitation Finally, rehabilitation for re-entry has become an essential mechanism for effective re-integration into society. Rigorous evidence shows promise for interventions offering support for offenders released to the community. For instance, Braga et al. (2009) evaluate the Boston Reentry Initiative, which offers comprehensive interventions (social, health, mentoring, and counseling services) to high-risk, violent criminals. They find that the program reduced recidivism rates by $30 \%$, relative to a matched comparison group. Bloom et al. (2007) conduct a randomized evaluation of a large prisoner re-entry program and show that there is a modest, but statistically significant, decline in felony convictions and incarceration for new crimes during the first year of follow-up.

In line with this, one promising approach to improving prisoner re-entry outcomes is cognitive behavioral therapy. There are several well-identified studies measuring the effect of cognitive behavioral therapy on recidivism. In general terms, results are somewhat mixed, and may depend on both the intensity of treatment as well as the quality of the instructors. For instance, Pearson et al. (2016) conduct a randomized control trial to test the effectiveness of a program (known as "Citizenship") in the United Kingdom that has a cognitive behavioral basis and focuses on education, promoting motivation to change, and community integration. They find that the program reduces convictions for high-risk probationers. Similarly, Barnes et al. (2017) use a randomized control trial to assess the impact of a cognitive behavioral therapy program on the recidivism of highrisk offenders. The analysis indicates that the overall cognitive behavioral therapy group was significantly less likely to reoffend, although this effect is concentrated in nonviolent offending. Heller et al. (2017) conduct three large-scale randomized control trial interventions to reduce crime and dropout rates by changing the decision-making of economically disadvantaged youth. They find support for the hypothesis that the programs 
work by helping youth slow down and reflect on thoughts and behaviors. Nevertheless, Bahr et al. (2016), who use a randomized control trial to evaluate a cognitive behavioral program that combines cognitive training, goal setting, and a phone-coach follow-up, find no effects on arrests.

Doleac (2018) reviewed the literature on re-entry programs in the U.S. and found that the programs that seem most promising are court-issued rehabilitation certificates, cognitive behavioral therapy, diversion from short incarceration spells, reducing intensity of community supervision, and expanding DNA databases. She found mixed evidence regarding the effectiveness of multisystemic therapy, and negative results on the effectiveness of transitional jobs programs, Ban the Box, and wrap-around services.

In summary, research has shown that deterrence and incapacitation are elements that help to reduce recidivism and overall crime. However, the fact that both homicide and incarceration rates in Latin America and the Caribbean have increased raises serious doubts about the proper functioning of these elements. Moreover, there are factors that favor the criminogenic effects of prisons in the region: high overcrowding rates, deficiencies in rehabilitation services and re-insertion of prisoners into society, and large numbers of prisoners without convictions. Empirical evidence supports the notion that re-entry programs and cognitive-behavioral therapy may be effective tools to reduce recidivism. Conversely, fear and punishment mechanisms are insignificantly effective. Doleac (2018) reviews re-entry programs in the U.S. and highlights the need for more evaluations to assess the effectiveness of the programs. This is even more pressing in countries in Latin America and the Caribbean where the prison population is growing exponentially and there is scant evidence on effective ways to reduce recidivism and achieve crime deterrence.

\subsection{Social prevention of violence}

Interventions for the social prevention of violence have been undertaken across multiple sectors. Evidence suggests that social and institutional interventions, including school attendance, self-control and conflict resolution, job training, and social interaction programs, can help mitigate risk factors. Under the framework of Sect. 3, the aim of these initiatives is to make legal activities more attractive among prospective criminals $\left(U^{\mathrm{nc}}\right)$ by increasing the cost of deviant behavior and reducing the gains from it, and hence reducing the overall return to deviant behavior.

\subsubsection{Educational attainment and quality}

There is quite strong evidence of a negative causal effect of educational attainment and quality on crime and incarceration rates. In a seminal paper, Lochner and Moretti (2004) find that a 1-year increase in the average education level reduces state arrest rates by $15 \%$ in the United States. Deming (2011) shows that attending a first-choice school leads to a $50 \%$ reduction in crime among high-risk youth, with defects lasting 7 years after random assignment, echoing previous evidence by Cullen et al. (2006) of reduced criminal activity. For the United Kingdom, Machin et al. (2011) find that a 1-year increase in average male educational attainment reduces incarceration rates by $20 \%$. Bell et al. (2016) offer a reassessment of the relationship between crime, compulsory schooling 
laws, and education. They report evidence of a significant reduced-form relationship between crime and compulsory schooling laws. The same causal mechanism was studied by Hjalmarrson et al. (2015), who find that an additional year of education reduces the incarceration rate for men by almost $16 \%$ in Sweden. Through an incapacitation effect, Jacob and Lefgren (2003) show that the level of property crime committed by juveniles decreases by $14 \%$ on days when school is in session.

In Colombia, Klevens et al. (2009) indicate that a teacher-delivered intervention was an effective mechanism to reduce aggressive behavior. Berthelon and Kruger (2011) analyze the effect of a school reform that lengthened the school day from half- to full-day shifts in Chile and find that the reform reduced youth crime. Obach et al. (2011) assess the effect of educational workshops held for young men in public schools in Chile and show a significant decline in the acceptance of violence as a conflict-resolution mechanism. In Brazil, Pulerwitz et al. (2006) study the effect of community campaigns that target young men about violence against women and find significant positive changes in 10 of 17 gender-attitude items for the treatment group 6 months after implementation, with no changes exhibited among program non-participants.

\subsubsection{Improvements in child development}

Related to the education findings, improvement of child development-especially in social-cognitive dimensions-is found to be promising for reducing crime. For instance, after 2 years in the Perry Program, a randomized trial that targeted disadvantaged, low IQ African American children aged 3-4, all participants left the program and entered the same public school. Data were collected for treatment and control groups through age 40 show that the Perry Program significantly enhanced adult outcomes, including education, employment, earnings, marriage, and participation in healthy behaviors, and reduced participation in crime (Belfield et al. 2006; Heckman et al. 2010a, b). Finally, Olds (2008) summarizes a 30-year research program that has attempted to improve the health and development of mothers and infants and their future life prospects through the use of prenatal and infancy home visits by nurses. The program was tested in a randomized trial. Results show that nurse-visited children reported fewer sexual partners, fewer criminal convictions, and fewer violations of probation among those who had been involved in criminal activity.

\subsubsection{Programs to help youth at risk}

Progress has also been made with regard to youth at risk, which generally includes youths who do not study or work. Along these lines, Heller et al. (2013) report results from a large randomized control trial of a cognitive-behavioral therapy intervention for disadvantaged male youth from high-crime Chicago neighborhoods. They find that program participation reduced violent crime arrests during the program year by $44 \%$, although the impact fades over time. Woolfenden, Williams, and Peat (2004) show that family and parenting interventions lead to a lower risk of being re-arrested. Piquero et al. (2009) provide evidence in support of parenting programs, indicating that treated young children who later got involved in criminal activity exhibited a 33\% recidivism rate, while $50 \%$ of the children in the control group for that category relapsed into criminal behavior. Van der Stouwe et al. (2014) report more modest but significant treatment 
effects on delinquency, particularly among juveniles under the age of 15 who had started out in particularly difficult circumstances. In contrast, Littell et al. (2005) analyze eight randomized control trials in the United States, Canada, and Norway and find no statistical effect of multi-systemic therapy on arrests and convictions.

\subsubsection{Skill programs and job-related interventions}

Programs to remedy youth unemployment may also help to reduce delinquent behavior. Under the setup of Sect. 2, the mechanism through which this occurs increases in the expected utility of legal activities $\left(U^{\mathrm{nc}}\right)$. However, these types of interventions face the challenge of integrating unskilled workers into the job market, which is especially difficult considering the role of technological change. It has been argued that the adoption of new technologies is positively correlated with the relative demand for skilled workers, and it has been a major determinant of the rise in wage inequality. In view of that, the results of the adoption of new technologies for workers are mixed. For example, Mocan and Unel (2011) investigate the impact of unskilled workers' earnings on crime using panel data and instrumental variables. Following the literature on wage inequality and skill-biased technological change, they find that technology-induced variations in unskilled workers' earnings affect property crime with an elasticity of -1 , but that wages have no impact on violent crime.

Regarding the effectiveness of these types of programs, Schaeffer et al. (2014) use a randomized control trial to evaluate the capacity of a promising vocational and employment training program in the construction sector. The program was focused on juvenile offenders with substance use problems. However, the study does not report favorable effects on measures of criminal activity. Schochet et al. (2008) analyze a large vocationally focused education and training program for disadvantaged youths in the United States, and show that approximately $33 \%$ of controls were arrested during the 48 -month follow-up period, compared to $29 \%$ of treatments. However, the authors conclude that, considering all measurable positive impacts, program costs are so high that they exceed program benefits for the full sample under most scenarios. On the other hand, there is convincing, albeit limited, evidence of the effectiveness of short-term and low-cost programs, such as summer jobs. Heller (2014) finds that assignment to a summer job program decreases violence by $43 \%$ over 16 months (3.95 fewer violent crime arrests per 100 youths). Gelber et al. (2014) study randomized lotteries for access to a summer youth employment program in New York City and find that participation in the program leads to a $10 \%$ reduction in the incarceration rate, relative to the baseline.

\subsubsection{Prevention of violence against women}

Violence prevention and care centers for women have been observed to reduce the likelihood of domestic violence. Randomized control trials in Washington, D.C. (Kiely et al. 2010), and Hong Kong (Tiwari et al. 2005) show significantly lower rates of violence revictimization among pregnant women who received psychosocial support, compared with women in control groups. Agüero (2013) examines the role of women's care centers in Peru and shows that, in general, the likelihood of violence decreases with age, although the gradient is steeper for districts with women's centers compared to those 
without them, providing empirical support for the theoretical model by Farmer and Tiefenthaler (1996).

In summary, educational attainment and quality are very effective crime-reducing mechanisms, and their effects are sustained over time. Cognitive behavioral programs appear to show the most favorable results. Improvement of child development-especially in social-cognitive dimensions-is promising for reducing crime. On the other hand, there is mixed evidence on the effectiveness of job-related interventions in reducing crime, as the challenge remains to introduce the role of skill-biased technological change into the design of these types of programs. Finally, violence prevention and care centers for women seem to be effective in reducing domestic violence.

\section{Avenues for future research and action in Latin America and the Caribbean}

As evidenced throughout this paper, there are important avenues for future research and action in Latin America and the Caribbean. Overall, there is a need to promote the generation and use of scientific evidence to inform policymaking in the security field. The costs of crime and violence are very high in the region and the impacts of insecurity are long lasting. For example, 33\% of deaths among young people aged 15-29 in Latin America and the Caribbean are due to interpersonal violence, with this being the main cause of death. In contrast, in developed countries, interpersonal violence accounts for $6 \%$ of deaths among the same age group (the main cause being road injuries, at $14 \%$ of the total), according to data from the Institute for Health Metrics and Evaluation. Clearly, the deaths of young people due to violence have inter-generational effects and an impact on growth and development in Latin America and the Caribbean.

Following Becker's crime economic framework and its successive extensions, the different policies and strategies to combat crime can be assessed to identify those that reduce the expected net benefit of committing crimes or increase the net benefit to legal activities.

Research conducted in Latin American contexts to date has shown interesting but scant results. For example, by increasing household income and mitigating the impact of income shocks, conditional cash transfer programs contribute to the prevention of crime and violence in Brazil, Colombia, and Mexico. Violence prevention and care centers for women have reduced the likelihood of domestic violence in Peru.

There are several studies suggesting that police presence can deter crime and disorder: both hot spot policing and community policing show significant success in reducing homicides and fear of crime in Chile and Colombia. In Uruguay, it has been shown that effective training on crime analysis can improve deployment of police resources and that better police training has the potential to reduce crime in places and times where crime is concentrated.

Issues relating to police organization are very important for the region, and research in Brazil has found that that the integration of police force operations leads to increased efficacy and reductions in crime. Finally, programs based mainly on fear or military discipline reveal no appreciable impact on recidivism, but electronic monitoring shows promising results in reducing relapses in criminal behavior in Argentina.

There remain many gaps in knowledge about crime prevention efforts, as many police strategies have yet to be rigorously tested. There is no clear understanding of the 
evolution of the disaggregated crime patterns and the roots of these high levels of violence. Furthermore, organized crime and drug issues might be exacerbating violence in some cities and specific contexts that need to be examined from a regional perspective.

The research agenda should also include assessing the effect of optimum curricula and multi-level behavioral interventions to prevent violence in youth at risk. For example, little is known about the effect of combining education or employability training with life skills to strengthen resilience to crime. Another area of vital importance is the study of violence against women.

On policing, the emphasis should be on the role of police in terms of deterrence rather than incapacitation, since the latter necessarily requires higher imprisonment rates, and overcrowding is already widespread in the region. It is still unclear which components of successful police reforms in the region are the most vital. For example, community policing and problem-oriented policing are features of police reforms in many countries and are worth studying. Police investigation is also a key area with room for improvement in the region.

Finally, in terms of criminal justice, a solid body of evidence is needed on the effect of imprisonment and most forms of extreme disciplinary mechanisms, particularly among minors and low-risk individuals. Research on the use of alternative approaches to prosecution-such as electronic monitoring, community work programs, drug courts, restorative justice meetings, cognitive behavioral therapies, and re-entry initiatives-are promising areas for future research.

Within all the areas covered in this paper, there are still unsettled questions globally and more so for Latin America and the Caribbean. On crime deterrence, the focus should be on increasing the efficiency of public spending on security and reducing impunity. A lot of resources in the region are spent on law enforcement, and the results are not encouraging. Better understanding of the nature of the security problems through the use of data and science would allow for better allocation of resources. And crime deterrence is a more cost-effective strategy than incarceration, not only because, as noted earlier, the results of incarceration on recidivism are not clear, but also because deterrence heads off all the subsequent spending on apprehension, sentencing, and incarceration.

There are two key elements to reducing crime that are important to develop. First is to better understand illegal markets and, more broadly, how economic incentives in terms of the returns to illegal activities affect crime. The second is related to the efficiency of public spending on security and in particular on improving policing.

In addition, various policies, such as increases in public spending, may have diverse effects on crime across countries and regions. Therefore, for future research, it is important to promote and implement impact evaluations of crime prevention and crime control policies to perform robust cost-benefit and cost-effectiveness analyses (Nagin 2015; Dhaliwal et al. 2013). It is urgent that the knowledge needed to apply evidencebased public policies in the region be developed, especially in the area of citizen security, where demands are pressing and research has been scarce. Also, it is very important to promote the dissemination of rigorous research that is the only way to build this public good of research the region needs. 


\subsection{Economic incentives and crime}

Apart from the losses and inconvenience of acquisitive crimes, thefts can become violent, producing further physical and psychological injuries. Robbery is an intrinsically violent crime, and, in fact, it is defined as theft accomplished by force or the threat of physical injury. In an extreme case, violent robbery proves fatal to the victim. This is a relatively rare event given that there are millions of thefts and robberies annually. Nevertheless, the probability of robbery homicides is a major contributor to the public's fear of crime. The costs associated with fatal robberies, the fear of getting robbed, and the psychological traumas caused by being robbed are clearly not included in the traditional welfare (consumer surplus + producer surplus) model. The size of this non-market externality seems to vary across countries.

More violent acquisitive crimes seem to be common in Latin America and the Caribbean, but less so in developed countries. According to the United Nations Office on Drugs and Crime, approximately $15 \%$ of robberies led to homicides in Latin America and the Caribbean in 2014, compared to the world average of 9.1\% (considering a sample of 33 countries). In countries such as Jamaica, $46 \%$ of homicide victims were killed during the commission of a robbery, compared to $5 \%$ in the United States.

This heightened degree of violence is also illustrated in victimization surveys. According to the 2014 Latin American Public Opinion Project Survey, armed robbery accounted on average for $26 \%$ of total crimes in the region in 2014. In contrast, in the United States, only 5\% of crimes were armed robberies. Furthermore, in 2014, 13\% of victims of crime in Latin America and the Caribbean were victims of unarmed robbery, but which involved assault or physical threat; while in the United States that figure was only $5 \%$ of crimes.

Therefore, it is important to study property crimes and how economic incentives affect the equilibrium crime rate, as this has important consequences for welfare in Latin America and the Caribbean.

Crime economics has focused mainly on the deterrence effects of changing the costs of committing crimes, particularly increases in the certainty, celerity, and severity of punishment through criminal justice system reforms or law enforcement interventions (for a review see Chalfin and McCrary 2017 and Nagin 2013). Another strand of the literature focuses on changes in the incentives to engage in legal activities and explores the relationship between crime and unemployment or crime and education (Bell et al. 2016; Fougère et al. 2009; Freeman 1999; Machin and Meghir 2004).

Less studied has been the question of how changes in the benefits from or returns to criminal activity affect observed crime levels. In the case of property theft, a key determinant of the benefits derived from crime is the financial value of stolen property, which is important both in terms of the resale potential of the property and the extent of its utility for the criminal's personal consumption. Thus, changes in these benefits may affect criminal participation decisions. There are a few empirical studies that address the issue of how the economic return of property crime may change crime levels. These include Reilly and Witt (2008) on changes in prices of audio-visual goods, and D'Este (2014) on the availability in the United States of pawnshops, which are usually associated with increasing opportunities to sell stolen goods. Also Draca et al. (2019) study how criminals respond to changes in prices by estimating crime-price elasticities drawn 
from a comprehensive crime dataset containing detailed information on stolen items for London between 2002 and 2012. They find significant positive crime-price elasticities for a panel of 44 consumer goods (mobile phones being number one) and for commodity-related goods (jewelry, fuel, and metal). The potential gains are a major empirical driver of criminal activity, and the changing structure of goods prices explains up to $15 \%$ of the observed fall in property crime across all goods categories as well as most of the sharp increases in commodity-related goods between 2002 and 2012.

The existing crime economics literature does not appear to have studied how the supply of goods may affect crime. One exception is a paper on durable goods and crime by Galiani et al. (2016), who develop a theoretical model to join the literature on durable goods and crime economics. Durability is a feature of the quality of the goods related to the speed at which the good deteriorates. Durability is a desirable feature, and most stolen goods are durable. In terms of the model, lowering durability reduces the incentives to steal durable goods. This would displace some criminals to other types of crime (crowding out) and also would reduce the incentives to engage in illegal activities (crowding in). The paper shows that perfect competition does not provide the optimal level of durability, unlike a model without crime; while the monopolist underproduces durability.

Further development of crime economics theory is needed. In general, crime issues are studied in partial-equilibrium settings, but the interconnectedness of agents' decisions requires general-equilibrium approaches (as in Galiani et al. 2016). And more generally, very little is known with regard to the other side of the market: the supply of stolen goods, mainly the stolen goods market. The degree of informality in a particular economy may play an important role in this regard, even more so in Latin America and the Caribbean.

\subsection{Improving the efficiency of public spending on security}

In recent years, Latin American and Caribbean countries have on average increased public spending on security, particularly for numbers of police officers. Around $2 \%$ of GDP of the region is spent on law enforcement (Jaitman 2017), of which around $80 \%$ is spent on the police (mainly personnel). Countries in the regions have diverse levels of spending on public safety which is allocated in different proportions for police services, prison administration and the judiciary. Figure 8 shows this allocation for the region. The level of public spending on security is uncorrelated with the incidence of crime (Jaitman 2017).

Police forces in the region do not seem to be very effective First, when comparing the size of police forces by region, on average Latin America and the Caribbean has 307 police officers per 100,000 population on average, a rate similar to the Middle East and North Africa (365) and Europe and Central Asia (378) and much higher than North America (222) and South Africa (125) (UNODC (United Nations Office on Drugs and Crime) 2015). However, both violent and property crimes are much higher in Latin American and Caribbean countries (see Sect. 2). Furthermore, while spending on other sectors such as health or education appears to be positively correlated with improved outcomes in those sectors, spending on citizen security has not been associated with improved security and lower crime rates. In fact, countries with similar spending levels 


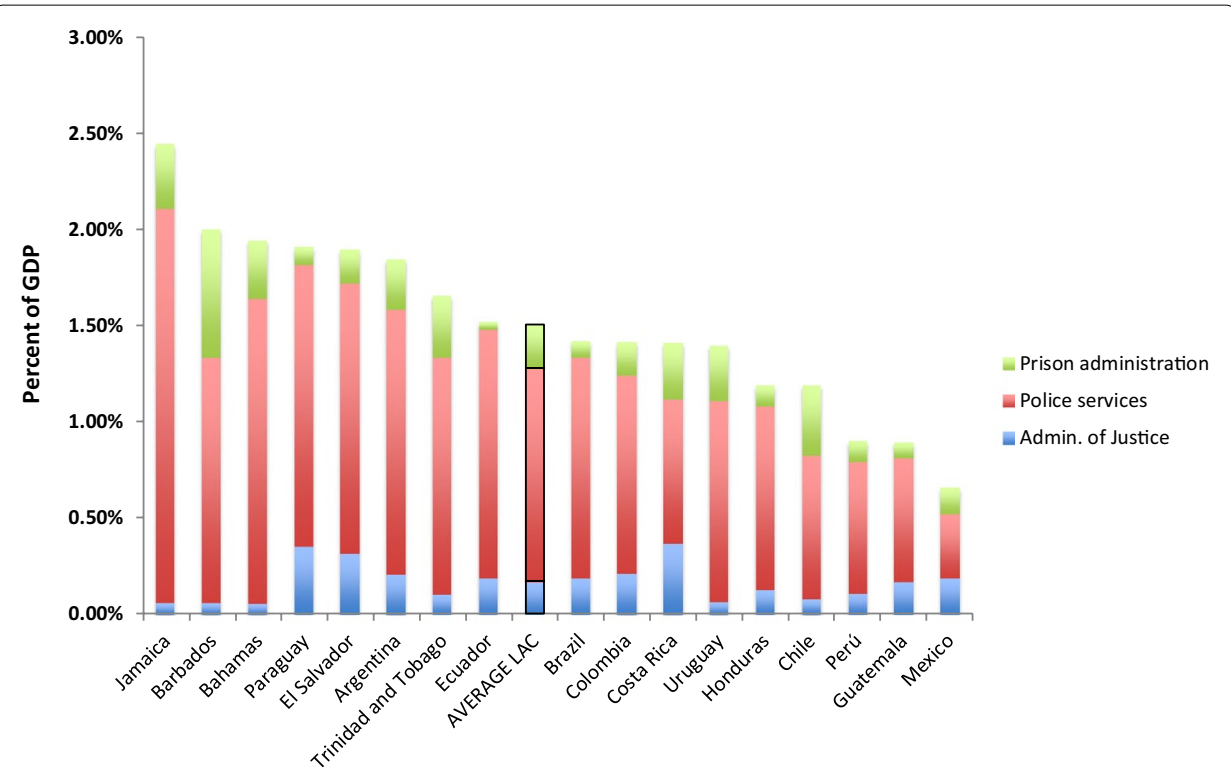

Fig. 8 Public spending on security. LAC Latin America and the Caribbean (Source: Prepared by the author based on national and sub-national budgets)

may have completely different homicide rates, suggesting the presence of potential inefficiencies in public spending. Second, when comparing public confidence in police forces by region, Latin American and Caribbean countries have a much lower level of confidence than the rest of the world (with the exceptions of Chile and Uruguay).

It is very challenging to measure the effectiveness of public spending in different areas. In citizen security in particular, it is even harder because ideally, we would need to know the inputs, the production function of security and then the outcomes. In security it has not been analyzed this production function in depth, and how the different inputs are combined. In the literature, some authors have used the Data Envelope Analysis (DEA) which has many shortcomings in settings like the region, as it involves assuming the same production function for countries with similar income (which is not the case in the region) and for the estimation the proxy for this production function is usually a function of the victimization rate which is correlated with crime.

Therefore, the most factual way to have an idea of the efficiency of public spending in security is to look at the inputs and outputs. In the case of security, despite the high number of police officers, the police do not seem to be very effective in the region, as the homicide rates are much higher in Latin American and Caribbean countries than in other regions of the world as Fig. 9a shows. The region is a clear outlier. While in other sectors such as health and education spending on personnel is as positively related to better outcomes as it is in countries on average across the world, in the area of security the region has much higher homicide rates than what would be predicted by the numbers of personnel on its police forces. To have a benchmark, we compare inputs and outcomes in other sectors. Figure 9b, c show that in both education and health sectors, there is a strong association between a larger number of inputs and better outcome variables. In terms of the performance of the region, in both sectors Latin America and the Caribbean countries are not outliers in the relationship between inputs and outcomes 


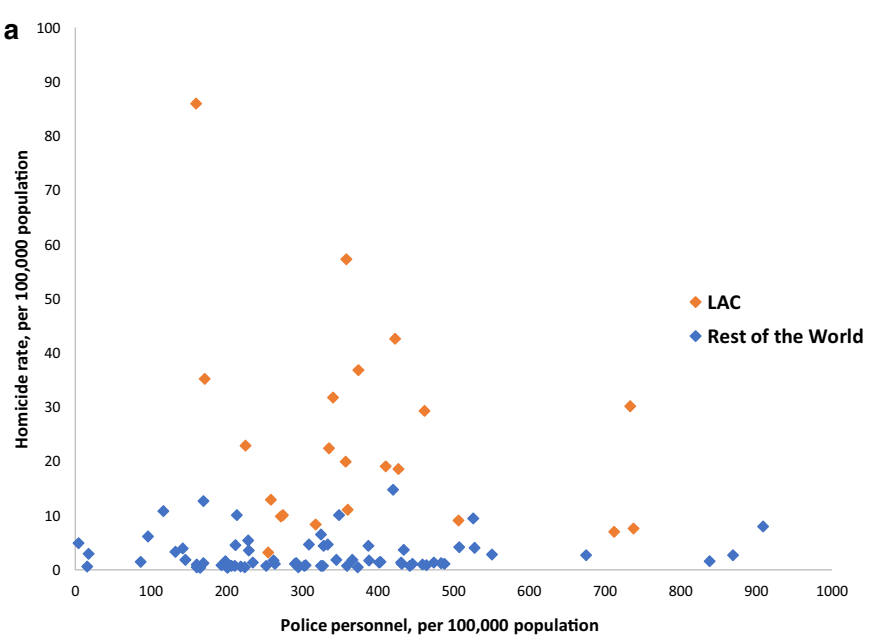

b 12
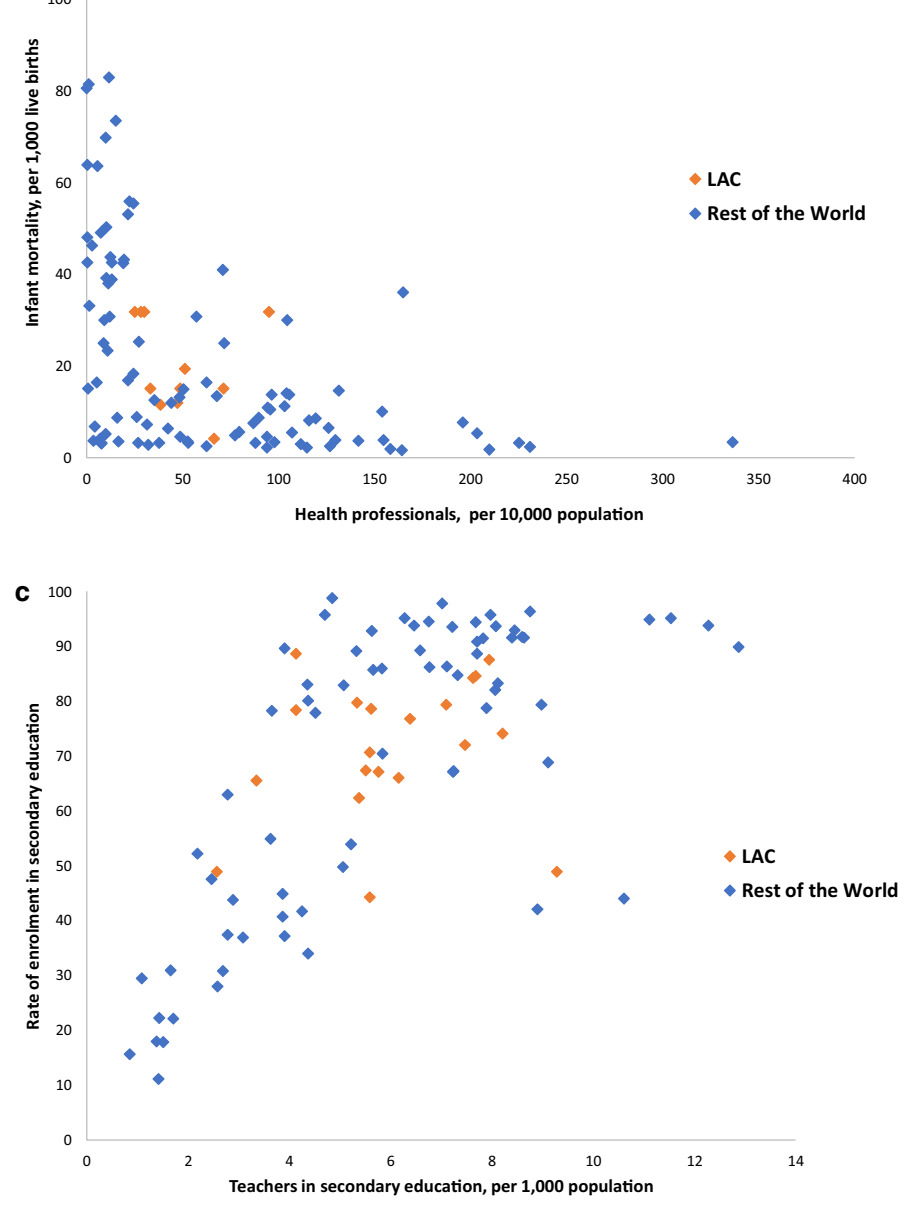

Fig. 9 a Police personnel and homicide rates. Source: Prepared by the author based on UNODC and World Bank World Development Indicators. b Health professionals and infant mortality. Source: Author's calculations based on World Bank World Development Indicators. c Teachers and school enrolment. Source: Author's calculations based on World Bank World Development Indicators. LAC Latin America and the Caribbean 
of health (health professionals and infant mortality) and education (teachers and school enrolment).

\subsubsection{Police reform}

Empirical studies of changes in police presence-whether those changes involve numbers of officers or their strategic deployment-consistently find positive effects on reducing crime (Nagin 2013). But a theoretical framework is still nonexistent.

There have been many changes in the staffing numbers and organization of police forces as part of police reforms. In developed democracies, police reform has generally followed what Kelling and Moore (1988) describe as three major eras of policing: the political era, the professional era, and the community policing era. However, scholars argue that policing in the twenty-first century is most likely characterized by yet a new era of policing (Bayley and Nixon 2010; Mazerolle and Ransley 2005; Stone and Travis 2011). While policing scholars debate the detail of these eras in policing history (Bayley 1994; Skogan 1990), they generally agree with the notion of four eras in the overall developmental sequence of policing through history. Some authors claim that this new era is one of the reinventions of policing in which the principles that should guide action are reducing crime and increasing trust.

Different police agencies in different developed democracies have progressed through these eras at different time periods. Policing in Latin America and the Caribbean could correspond to different eras according to the country or even the city. In many countries the political era and the influence of politics in police and the administration of justice is prominent. In other countries, reforms are under way to improve recruiting, qualifications, and accountability more associated with the professional era. There are also hybrid cases.

However, there appears to be a gap in the literature on police reform regarding how to conceptualize police reforms and counter-reforms. Although the effect of different interventions can be explained using the Becker (1968) crime economics framework-as police can increase the certainty, celerity, and (sometimes) severity of the potential costs of committing crimes (e.g., fines, sentences) - these changes are usually undertaken within police reforms that have not been studied yet. A model of police reform would be a very important contribution.

On the empirical side, policing strategy is an area where experimental and quasiexperimental methods gradually are becoming a powerful research tool. Despite these advances, however, there is still a knowledge gap between police crime prevention efforts and how the overall knowledge can inform the implementation of effective strategies. Many police strategies have to be rigorously evaluated, and the current literature indicates many ambiguities in this regard (Weisburd et al. 2001).

In short, there is a dearth of literature on police strategies in Latin America and the Caribbean. This may suggest that problem-oriented policing, community policing, and especially improved coordination of police forces are proving to be successful in reducing crime. Community policing and problem-oriented policing are features of police reforms that many countries in the region are pursuing. Evaluations in these areas, therefore, should be a priority. In line with this, technology is changing the way police forces work worldwide, as it affects criminal analysis and investigations alike. 


\section{Thus, carrying out cutting-edge research on the role of technology in policing is also} fundamental.

\section{Abbreviations}

DNA: deoxyribonucleic acid; ETAS: epidemic-type aftershock sequence; GDP: gross domestic product; IQ: intelligence quotient; PPP: purchasing power parity; UNDP: United Nations Development Programme; UNODC: United Nations Office on Drugs and Crime; WHO: World Health Organization.

\section{Acknowledgements}

Victoria Anauati provided excellent research assistance.

\section{Authors' contributions}

$\mathrm{L}$ is responsible for the writing of this paper. The author read and approved the final manuscript.

\section{Funding}

None.

Availability of data and materials

No datasets were generated for the current study.

Competing interests

The author declares no competing interests.

Received: 30 September 2019 Accepted: 20 November 2019

Published online: 12 December 2019

\section{References}

Agüero J (2013) Causal estimates of the intangible costs of violence against women in Latin America and the Caribbean. IDB Working Paper No. 414. Inter-American Development Bank, Washington, DC

Aizer A, Doyle JJ (2015) Juvenile incarceration, human capital, and future crime: evidence from randomly assigned judges. Q J Econ 130(2):759-803

Alves MC, Arias ED (2012) Understanding the Fica Vivo Programme: two-tiered community policing in Belo Horizonte, Brazil. Policing Soc 22(1):101-113

Bahr SJ, Cherrington DJ, Erickson LD (2016) An evaluation of the impact of goal setting and cell phone calls on juvenile rearrests. Int J Offender Ther Comp Criminol 60(16):1816-1835

Baloian N, Bassaletti E, Fernandez M, Figueroa O, Fuentes P, Manasevich R, Orchard M, S Peñafiel, Pino J, Vergara M (2017) Proceedings of the 2017 IEEE 21st international conference on computer supported cooperative work in design, CSCWD 2017, 8066662: 2-9

Barnes GC, Hyatt JM, Sherman LW (2017) Even a little bit helps: an implementation and experimental evaluation of cognitive-behavioral therapy for high-risk probationers. Crim Justice Behav 44(4):611-630

Bayley DH (1994) Police for the future. Oxford University Press, New York

Bayley DH, Nixon C (2010) The changing environment for policing, 1985-2008. Harvard Kennedy School Program in Criminal Justice Policy and Management

Becker GS (1968) Crime and punishment: an economic approach. J Polit Econ 76(2):169-217

Belfield CR, Nores M, Barnett S, Schweinhart L (2006) The High/Scope Perry Preschool Program. J Hum Resour $\mathrm{XLI}(1): 162-190$

Bell B, Jaitman L, Machin S (2014) Crime deterrence: evidence from the London 2011 riots. Econ J 124(576):480-506

Bell B, Costa R, Machin S (2016) Crime, compulsory schooling laws and education. Econ Educ Rev 54:214-226

Bennett Moses L, Chan J (2016) Algorithmic prediction in policing: assumptions, evaluation, and accountability. Policing Soc 28(7):806-822

Berthelon ME, Kruger DI (2011) Risky behavior among youth: incapacitation effects of school on adolescent motherhood and crime in Chile. J Public Econ 95(1-2):41-53

Bloom D, Redcross C, Zweig J, Azurdia G (2007) Transitional jobs for ex-prisoners early impacts from a random assignment evaluation of the Center for Employment Opportunities (CEO) Prisoner Reentry Program. U.S. Department of Health and Human Services, Washington, DC

Bowers KJ, Johnson SD, Guerette RT, Summers L, Poynton S (2011) Spatial displacement and diffusion of benefits among geographically focused policing initiatives. J Exp Criminol 7:347-374

Braga AA (2001) The effects of hot spots policing on crime. Ann Am Acad Polit Soc Sci 578:104-125

Braga AA (2007) Effects of hot spots policing on crime. Campbell Syst Rev 2007:1

Braga AA, Bond BJ (2008) Policing crime and disorder hot spots: a randomized controlled trial. Criminology. 46(3):577-607

Braga AA, Weisburd DL (2012) Pulling levers focused deterrence strategies to prevent crime. Crime Prevention Research Review 6. U.S. Department of Justice, Office of Community Oriented Policing Services, Washington, DC

Braga AA, Weisburd DL, Waring EJ, Mazerolle LG, Spelman W, Gajewski F (1999) Problem-oriented policing in violent crime places: a randomized controlled experiment. Criminology 37:541-580

Braga AA, Piehl AM, Hureau D (2009) Controlling violent offenders released to the community: an evaluation of the Boston Reentry Initiative. J Res Crime Delinq 46(4):411-436 
Buonanno P, Raphael S (2013) Incarceration and incapacitation: evidence from the 2006 Italian collective pardon. Am Econ Rev 103:2437-2465

Bushway SD, Owens EG (2013) Framing punishment: incarceration, recommended sentences, and recidivism. J Law Econ 56(2):301-331

Caetano G, Maheshri V (2014) Identifying dynamic spillovers in criminal behavior. Working Paper. https://ssrn.com/abstr act $=2460952$

Caeti TJ, Fritsch EJ, Taylor RW (1999) Gang suppression through saturation patrol, aggressive curfew, and truancy enforcement: a quasi-experimental test of the Dallas anti-gang initiative. Crime Deling 45(1):122-139

Chainey S, Tompson L, Uhlig S (2008) The utility of hotspot mapping for predicting spatial patterns of crime. Secur J 21(1-2):4-28

Chalfin A, McCrary J (2017) Criminal deterrence: a review of the literature. J Econ Lit 55(1):5-48

Chen KM, Shapiro JM (2007) Do harsher prison conditions reduce recidivism? A discontinuity-based approach. Am Law Econ Rev 9(1):1-29

Cohen J, Ludwig J (2003) Policing crime guns. In: Ludwig J, Cook PJ (eds) Evaluating gun policy: Effects on crime and violence. Brookings Institution Press, Washington, DC

Cullen JB, Jacob BA, Levitt SD (2006) The effect of school choice on participants: evidence from randomized lotteries. Econometrica 74(5):1191-1230

D'Este R (2014) The effect of stolen goods markets on crime: Pawnshops, property thefts and the Gold Rush of the 2000s. University of Warwick Working Paper (Unpublished)

Deming D (2011) Better schools, less crime? Quart J Econ 126(4):2063-2115

Dhaliwal I, Duflo E, Glennerster R, Tulloch C (2013) Comparative cost-effectiveness analysis to inform policy in developing countries: A general framework with applications for education. In: Glewwe P (ed) Education policy in developing countries. University of Chicago Press, Chicago

Di Tella R, Schargrodsky E (2004) Do police reduce crime? Estimates using the allocation of police forces after a terrorist attack. Am Econ Rev 94(1):115-133

Di Tella R, Galiani S, Schargrodsky E (2010) Crime distribution and victim behavior during a crime wave. In: Di Tella R, Edwards S, Schargrodsky E (eds) The economics of crime: lessons for and from Latin America. University of Chicago Press, Chicago

Doleac J (2018) Strategies to productively reincorporate the formerly-incarcerated into communities: a review of the literature. IZA Discussion Paper No. 11646

Draca M, Machin S (2015) Crime and economic incentives. Ann Rev Econ 7(1):389-408

Draca M, Machin S, Witt R (2011) Panic on the streets of London: police, crime, and the July 2005 terror attacks. Am Econ Rev 101(5):2157-2181

Draca M, Koutmeridis T, Machin S (2019) The changing returns to crime: do criminals respond to prices? Rev Econ Stud 86(3):1228-1257

Drago F, Galbiati R, Vertova P (2009) The deterrent effects of prison: evidence from a natural experiment. J Polit Econ $117(2): 257-280$

Drago F, Galbiati R, Vertova P (2011) Prison conditions and recidivism. Am Law Econ Rev 13(1):103-130

Eck JE, Weisburd D (1995) Crime and place, crime prevention studies. Criminal Justice Press, New York

Evans DJ, Herbert DT (eds) (1989) The geography of crime. Routledge, London

Evans WN, Owens EG (2007) COPS and crime. J Public Econ 91(1):181-201

Farmer A, Tiefenthaler J (1996) Domestic violence: the value of services as signals. Am Econ Rev 86(2):274-279

Felson M (1987) Routine activities and crime prevention in the developing metropolis. Criminology 25(4):911-932

Ferguson AG (2016) Policing predictive policing. Washington University Law Review 94(5):1109

Fougère D, Kramarz F, Pouget J (2009) Youth unemployment and crime in France. J Eur Econ Assoc 7(5):909-938

Freeman RB (1999) The economics of crime. In: Ashenfelter O, Card D (eds) Handbook of labor economics, vol 3c. North Holland, Amsterdam

Gaes G, Camp S (2009) Unintended consequences: experimental evidence for the criminogenic effect of prison security level placement on post-release recidivism. J Exp Criminol 5(2):139-162

Galiani S, Jaitman L (2016) Predictive policing in Latin America: Experimental evidence from two randomized controlled trials. Mimeo

Galiani S, Rossi M, Schargrodsky E (2011) Conscription and crime: evidence from the Argentine draft lottery. Am Econ J Appl Econ 3(2):119-136

Galiani S, Jaitman L, Weinschelbaum F (2016) Crime and durable goods. NBER Working Paper No. 22788. National Bureau of Economic Research, Cambridge, MA

Galiani S, Jaitman L, Soares R, Guest editors (2019) Special issue: 50 years of the economics of crime. J Econ Behav Organ 159:421-662

Gelber A, Isen A, Kessler JB (2014) The effects of youth employment: Evidence from New York City summer youth employment program lotteries. NBER Working Paper No. 20810. National Bureau of Economic Research, Cambridge, MA

Gill C, Wooditch A, Weisburd D (2017) Testing the "law of crime concentration at place" in a suburban setting: implications for research and practice. J Quant Criminol 33(3):519-545

Heckman JJ, Moon SH, Pinto R, Savelyev PA, Yavitz A (2010a) The rate of return to the High Scope Perry Preschool Program. J Public Econ 94(1-2):114-128

Heckman J, Moon SH, Pinto R, Savelyev P, Yavitz A (2010b) Analyzing social experiments as implemented: a reexamination of the evidence from the High Scope Perry Preschool Program. Quant Econ 1(1):1-46

Heller SB (2014) Summer jobs reduce violence among disadvantaged youth. Science 346(6214):1219-1223

Heller SB, Pollack HA, Ander R, Ludwig J (2013) Preventing youth violence and dropout: A randomized field experiment. NBER Working Paper No. 19014. National Bureau of Economic Research, Cambridge, MA

Heller SB, Shah AK, Guryan J, Ludwig J, Mullainathan S, Pollack HA (2017) Thinking, fast and slow? Some field experiments to reduce crime and dropout in Chicago. Q J Econ 132(1):1-54 
Hjalmarrson R, Holmlund H, Lindquist MJ (2015) The effect of education on criminal convictions and incarceration: causal evidence from micro-data. Econ J 125(587):1290-1326

Hunt P, Saunders J, Hollywood JS (2014) Evaluation of the Shreveport predictive policing experiment. Rand Corporation, Santa Monica

Jacob BA, Lefgren L (2003) Are idle hands the devil's workshop? Incapacitation, concentration and juvenile crime. Am Econ Rev 93(5):1560-1577

Jaitman L (ed) (2015) The welfare costs of crime and violence in Latin America and the Caribbean. Inter-American Development Bank, Washington DC

Jaitman L (ed) (2017) The costs of crime and violence: new evidence and insights in Latin America and the Caribbean. Inter-American Development Bank, Washington DC

Johnson SD, Bernasco W, Bowers KJ, Elffers H, Ratcliffe J, Rengert G, Townsley M (2007) Space-time patterns of risk: a cross national assessment of residential burglary victimization. J Quant Criminol 23(3):201-219

Kelling GL, Moore MH (1988) The evolving strategy of policing. U.S. Department of Justice, Office of Justice Programs, National Institute of Justice, Washington, DC

Kennedy DM (2006) Old wine in new bottles: policing and the lessons of pulling levers. In: Weisburd DL, Braga AA (eds) Police innovation: contrasting perspectives. Cambridge University Press, New York

Kennedy DM, Braga AA, Waring EJ, Piehl AM (2001) Problem-oriented policing, deterrence, and youth violence: an evaluation of Boston's Operation Ceasefire. J Res Crime Delinq 38(3):195-225

Kennedy LW, Caplan JM, Piza E (2011) Risk clusters, hotspots, and spatial intelligence: risk terrain modeling as an algorithm for police resource allocation strategies. J Quant Criminol 27(3):339-362

Kiely M, El-Mohandes AA, El-Khorazaty MN, Blake SM, Gantz MG (2010) An integrated intervention to reduce intimate partner violence in pregnancy: a randomized controlled trial. Obstet Gynecol 115:273-283

Klevens J, Martínez JW, Le B, Rojas C, Duque A, Tovar R (2009) Evaluation of two interventions to reduce aggressive and antisocial behavior in first and second graders in a resource-poor setting. Int J Educ Res 48(5):307-319

Klick J, Tabarrok A (2005) Using terror alert levels to estimate the effect of police on crime. J Law Econ 48(1):267-279

Latinobarómetro (2017) Latinobarómetro: Opinión púbica latinoamericano. Santiago. http://www.latinobarometro.org/ lat.jsp

Lee DS, McCrary J (2009) The deterrence effect of prison: Dynamic theory and evidence. Industrial Relations Section Working Paper No. 550. Princeton University, Princeton, NJ

Levitt S (1997) Using electoral cycles in police hiring to estimate the effect of police on crime. Am Econ Rev 87(3):270-290

Levitt S (2002) Using electoral cycles in police hiring to estimate the effect of police on crime: a reply. Am Econ Rev 92:1244-1250

Littell JH, Popa M, Forsythe B (2005) Multisystemic therapy for social, emotional, and behavioral problems in youth aged 10-17. Cochrane Database Syst Rev 4:1-51

Lochner L, Moretti E (2004) The effect of education on crime: evidence from prison inmates, arrests and self-reports. Am Econ Rev 94(1):155-189

MacDonald JM, Klick J, Grunwald B (2016) The effect of private police on crime: evidence from a geographic regression discontinuity design. J R Stat Soc Ser A 179(3):831-846

Machin S, Meghir C (2004) Crime and economic incentives. J Hum Resour 39(4):958-979

Machin S, Marie O, Vujić S (2011) The crime reducing effect of education. Econ J 121 (552):463-484

Mastrobuoni G (2017) Crime is terribly revealing: Information technology and police productivity. https://ssrn.com/abstr act $=2989914$

Mazerolle L, Ransley J (2005) Third party policing. Cambridge University Press, Cambridge

McCrary J (2002) Do electoral cycles in police hiring really help us estimate the effect of police on crime? Comment. Am Econ Rev 92:1236-1243

Mocan N H, Unel B (2011) Skill-biased technological change, earnings of unskilled workers, and crime. NBER Working Paper No. 17605. National Bureau of Economic Research, Cambridge, MA

Mohler GO, Short MB, Malinowski S, Johnson M, Tita GE, Bertozzi AL, Brantingham PJ (2015) Randomized controlled field trials of predictive policing. J Am Stat Assoc 110(512):1399-1411

Nagin DS (2013) Deterrence: a review of the evidence by a criminologist for economists. Ann Rev Econ 5(1):83-105

Nagin DS (2015) Cost-benefit analysis of crime prevention policies. Criminol Public Policy 14(4):583-587

National Academies of Sciences, Engineering, and Medicine (2018) Proactive policing: Effects on crime and communities. The National Academies Press, Washington, DC. https://doi.org/10.17226/24928

Obach A, Sadler M, Aguayo F (2011) Involucrando hombres jóvenes en el fin de la violencia de género: Intervención multipaís con evaluación de impacto: caso Chileno. CulturaSalud/EME, Santiago

Olds DL (2008) Preventing child maltreatment and crime with prenatal and infancy support of parents: the nurse-family partnership. J Scand Stud Criminol Crime Prev 9(S1):2-24

Owens EG (2009) More time, less crime? Estimating the incapacitative effect of sentence enhancements. J Law Econ 52:551-579

Pearson DA, McDougall C, Kanaan M, Torgerson DJ, Bowles RA (2016) Evaluation of the citizenship evidence-based probation supervision program using a stepped wedge cluster randomized controlled trial. Crime Delinq 62(7):899-924

Perry W, McInnis B, Price CC, Smith S, Hollywood S (2013) Predictive policing: The role of crime forecasting in law enforcement operations. Rand Corporation, Santa Monica

Peters M (1996a) Evaluation of the impact of boot camps for juvenile offenders: Denver interim report. NCJRS Document Reproduction Service No. 160927. U.S. Department of Justice/Office of Juvenile Justice and Delinquency Prevention

Peters M (1996b) Evaluation of the impact of boot camps for juvenile offenders: Mobile interim report. NCJRS Document Reproduction Service No. 160926. U.S. Department of Justice/Office of Juvenile Justice and Delinquency Prevention 
Petrosino A, Turpin-Petrosino C, Buehler J (2003) Scared Straight and other juvenile awareness programs for preventing juvenile delinquency: a systematic review of the randomized experimental evidence. Ann Am Acad Polit Soc Sci 589(1):41-62

Philippe A (2013) The deterrent effect of an increase in sentence time: Evidence from French peines planchers. Université de Paris 1 Panthéon-Sorbonne/CREST (Unpublished)

Pierce GL, Spaar S, Briggs LR (1988) The character of police work: Strategic and tactical implications. Center for Applied Social Research, Northeastern University

Piquero AR, Farrington DP, Welsh BC, Tremblay R, Jennings WG (2009) Effects of early family/parent training programs on antisocial behavior and delinquency. J Exp Criminol 5:83-120

Polinsky AM, Shavell S (1999) On the disutility and discounting of imprisonment and the theory of deterrence. J Lega Stud 28(1):1-16

Posner RA (2004) Frontiers of legal theory. Harvard University Press, Cambridge

Pulerwitz J, Barker G, Segundo M, Nascimento M (2006) Promoting more gender-equitable norms and behaviors among young men as an HIV/AIDS prevention strategy. Horizons Final Report, Population Council, Washington, DC

Ratcliffe JH, Taniguchi T, Groff ER, Wood JD (2011) The Philadelphia foot patrol experiment: a randomized controlled trial of police patrol effectiveness in violent crime hotspots. Criminology 49(3):795-831

Reilly B, Witt R (2008) Domestic burglaries and the real price of audio-visual goods: some time series evidence for Britain. Econ Lett 100(1):96-100

Saunders J, Hunt P, Hollywood JS (2016) Predictions put into practice: a quasi-experimental evaluation of Chicago's predictive policing pilot. J Exp Criminol 12(3):347-371

Schaeffer CM, Henggeler SW, Ford JD, Mann M, Chang R, Chapman JE (2014) RCT of a promising vocational/employment program for high-risk juvenile offenders. J Subst Abuse Treat 46(2):134-143

Schochet PZ, Burghardt J, McConnell S (2008) Does Job Corps work? Impact findings from the National Job Corps Study. Am Econ Rev 98(5):1864-1886

Sherman LW, Rogan DP (1995) Effects of gun seizures on gun violence: "Hot spots" patrol in Kansas City. Justice Q 12(4):673-693

Sherman LW, Weisburd D (1995) General deterrent effects of police patrol in crime 'hot spots': a randomized, controlled trial. Justice Q 12:625-648

Skogan WG (1990) The police and the public in England and Wales: a British crime survey report. HM Stationery Office, London

Stone C, Travis J (2011) Towards a new professionalism in policing. New perspectives in policing bulletin, U.S. Department of Justice, National Institute of Justice, NCJ 232359, Washington, DC

Taylor B, Koper CS, Woods DJ (2011) A randomized controlled trial of different policing strategies at hot spots of violent crime. J Exp Criminol 7(2):149-181

Telep CW, Mitchell RJ, Weisburd D (2012) How much time should the police spend at crime hot spots? Answers from a police agency directed randomized field trial in Sacramento, California. Justice Q 31(5):905-933

Thomas D, Peters M (1996) Evaluation of the impact of boot camps for juvenile offenders: Cleveland interim report. NCJRS Document Reproduction Service No. 160928. U.S. Department of Justice/Office of Juvenile Justice and Delinquency Prevention

Tiwari A, Leung WC, Leung TW, Humphreys J, Parker B, Ho PC (2005) A randomised controlled trial of empowerment training for Chinese abused pregnant women in Hong Kong. BJOG 112:1249-1256

UNDP (United Nations Development Programme) (2013) Informe regional de desarrollo humano 2013-2014: Seguridad ciudadana con rostro humano: diagnóstico y propuestas para América Latina. UNDP, New York

UNODC (United Nations Office on Drugs and Crime) (2015) Report of the United Nations Office on Drugs and Crime on the international classification of crime for statistical purposes. https://unstats.un.org/unsd/class/intercop/exper tgroup/2015/AC289-28.PDF

UNODC (United Nations Office on Drugs and Crime) (2019) Global Study on Homicide 2019. UN, Vienna. https://www. unodc.org/unodc/en/data-andanalysis/global-study-on-homicide.html

Van der Stouwe T, Asscher JJ, Stams GJJM, Deković M, van der Laan PH (2014) The effectiveness of multisystemic therapy: a meta-analysis. Clin Psychol Rev 34(6):468-481

Vollaard B (2013) Preventing crime through selective incapacitation. Econ J 123(567):262-284

Weisburd D (2015) The law of crime concentration and the criminology of place. Criminology 53(2):133-157

Weisburd D, Green L (1994) Defining the street-level drug market. In: MacKenzie DL, Uchida CD (eds) Drugs and crime: Evaluating public policy initiatives. Sage Publications, Thousand Oaks

Weisburd D, Lum CM, Petrosino A (2001) Does research design affect study outcomes in criminal justice? Ann Am Acad Polit Soc Sci 578(1):50-70

Wells JB, Minor Kl, Angel E, Stearman KD (2006) A quasi-experimental evaluation of a shock incarceration and aftercare program for juvenile offenders. Youth Viol Juv Justice 4(3):219-233

WHO (World Health Organization) (2013) Global and regional estimates of violence against women: Prev-alence and health effects of intimate partner violence and non-partner sexual violence. http://apps.who.int/iris/bitst ream/10665/85239/1/9789241564625_eng.pdf

Wilson JQ, Kelling GL (1982) Broken windows. Atlant Monthly 249(3):29-38

Woolfenden S, Williams KJ, Peat J (2004) Family and parenting interventions in children and adolescents with conduct disorder and delinquency aged 10-17. Cochr Database Syst Rev 2:1-30

Zhang SX (2000) An evaluation of the Los Angeles County Juvenile Drug Treatment Boot Camp

\section{Publisher's Note}

Springer Nature remains neutral with regard to jurisdictional claims in published maps and institutional affiliations. 